\title{
Proměny a konstanty Helfertova psaní o Janáčkovi
}

\section{Transformations and Constants of Helfert's Writing on Janáček}

\author{
Miloš Zapletal / M.Zapletal1987@gmail.com \\ Ústav hudební vědy FF MU, Brno; Akademie věd ČR, CZ
}

\begin{abstract}
The study deals with development of Vladimír Helfert's writing about Leoš Janáček from the period 1911-1939 and presents the results of a discourse analysis of Helfert's texts (both musical-critical and historiographical) on Janáček. In his texts, Helfert ignored Janáček until the beginning of the First World War: this was the time of "struggle against Dvořák", in which Helfert stood on Zdeněk Nejedly's side. Helfert wrote his first text on Janáček in 1915, but it was not until he moved to Brno in the summer of 1919 that he began to regard Janáček favourably. The turnover in his writing on Janáček occurred in 1920, when Helfert transformed some former conceptual negatives into positives. After Janáčekian anniversary festival in 1924, Helfert started to write about Janáček more frequently and systematically, and, around 1925, a coherent critical conception of Janáček started to emerge from his writing. In many aspects, it was similar to Nejedly's conception of the Great Czech Composer. In the following years, Helfert further developed this conception and gradually recognized Janáček as a classical figure of modern Czech music; this process culminated in the first part of his unfinished monograph on Janáček from 1939. The basic features of his conception are the following: (1) organicity of Janáček's artistic development and inclusion of Janáček into the organicist model of the evolution of modern Czech music; (2) contraposition of Janáček and other great Czech composers, and the view of Janáček as a sheer individuality; (3) recognition of some negatives of Janáček's musical thought as positives in their own rightspecific qualities ("elementariness", non-constructiveness, aphoristicity, etc.); (4) Janáček as a completely new, revolutionary type of composer; (5) identity of the character of the composer's personality and the character of his music; (6) Janáček as a primarily vocal and dramatic composer; (7) Janáček as a Beethovenian genius; (8) the myth of eternally young Janáček; (9) Janáček as an essential realist and, therefore, anti-romantic; and (10) emphasising Janáček's Russianisms or Slavicness.
\end{abstract}

\section{Key words}

Helfert, Janáček, reception of music, discourse analysis, writing (écriture), music criticism, methodology of music history, conceptions of history 
Není úplně běžné psát dějiny recepce jednoho skladatele jedním kritikem. ${ }^{1} \mathrm{~V}$ př́padě vztahu Helfert-Janáček je však podobně zacílený výklad namístě, a to zejména ze dvou důvodů: zaprvé proto, že postoj k Janáčkovi představuje uhelný kámen vývoje Helfertova muzikologického myšlení a psaní, ${ }^{2}$ zadruhé pak proto, že Vladimír Helfert byl a dodnes je jedním ze stěžejních janáčkovských kritiků (jak v užším, tak i širším smyslu tohoto slova).

Přestože existuje několik odborných textů zabývajících se vztahem Helfert-Janáček, ${ }^{3}$ vývoj a strukturní analýzu Helfertova psaní o Janáčkovi - poněkud překvapivě - dosud nikdo nepojednal. V této studii podávám hrubý nástin a přehled Helfertova psaní o Janáčkovi. Slovem „psaní“ vyjadřuji jednak skutečnost, že jsem analýze podrobil všechny Helfertovy texty, v nichž se vyjadřuje o Janáčkovi, tedy nejen texty kritické $\mathrm{v}$ užším slova smyslu (jakkoliv v Helfertově psaní o Janáčkovi není hranice mezi „vědou“ a „kritikou“ ostrá), ${ }^{4}$ jednak jím odkazuji na francouzský termín écriture, jak je užíván v poststrukturalistickém myšlení o literatuře. ${ }^{5}$

Hned úvodem je třeba zdůraznit, že se chci vyhnout naivnímu ztotožňování autorových textů a systému jeho psaní s jeho názory. Nesleduji zde tedy vývoj Helfertových názorů na Janáčka (takový podnik není vyloučen, ale vyžadoval by především odlišnou metodu a jiný typ pramenů), nezabývám se zde Helfertovým estetickým systémem, ${ }^{6}$ a ani se nesnažím převyprávět uklidňující př́íběh o tom, kterak se Helfert dosáhnuv Kristo-

1 Takto orientované jsou např. následující studie: POSPÍŠIL, Milan. Bedřich Smetana v pojetí Elišky Krásnohorské. Hudebni věda, 1995, roč. 32, č. 1, s. 42-54. BURNHAM, Scott. Criticism, Faith, and the Idee: A. B. Marx's Early Reception of Beethoven. 19th-Century Music, 1990, roč. 13, č. 3, s. 183-192. ZAGORSKI, Marcus. Hearing Beethoven, Truth, and "New Music". International Review of the Aesthetics and Sociology of Music, 2013, roč. 44 , č. 1 , s. $49-56$.

2 Kromě Smetany je Janáček nejhojněji zastoupeným skladatelem v helfertovské bibliografii. Viz POLEDŇÁK, Ivan. Soupis prací Vladimíra Helferta. Musikologie, 1958, č. 5, s. 253-313.

3 K přehledu Helfertova hudebního kriticismu viz HONS, Miloš. Boj o českou moderni hudbu (1900-1939). Praha: Togga, 2013, s. 41-48. Kromě dále cit. studií zde třeba zmínit zejm.: FUKAČ, Jiří. Helfert analytik. In Vladimír Helfert v českém a evropském kontextu. Brno: Svaz českých skladatelů a koncertních umělců, 1987, s. 20-23; PEČMAN, Rudolf. Vladimír Helfert. Brno: Nadace Universitas Masarykiana, 2003; VYSLOUŽIL, Jiř́i. Index - tribuna Helfertových kritických syntéz. Index, 1968, roč. 1, č. 7, s. 24-29; č. 8, s. 22-25; VYSLOUŽIL, J. Vladimír Helfert as a Critic of Music. SPFFBU, 1969, H4 (roč. 4), č. 18, s. 49-66. K Helfertově recepci Janáčkovy sborové tvorby v $\check{C} M H$ viz HONS, Miloš. Česká sborová tvorba očima Helfertovy České moderní hudby. In Helfertova Česká moderni hudba. Praha: HAMU, 1996, s. 57.

4 Podle Hrabala byla Helfertova hudebně kritická práce „součastí a aplikací Helfertovy vědy“. HRABAL, František. Pohled na Vladimíra Helferta. In Vladimír Helfert. Vybrané studie I. O hudebni tvorívosti. Praha: Editio Supraphon, 1970, s. 9.

5 Tedy jako termín „vyznačujici povahu p[saní]., ale i mluvené komunikace, která je sama o sobě založená nikoliv referenčně [...], nýbrž strukturně a diferenčně ( $t$. odkazy na rozdily v rámci struktur) jako soubor vztahů vzájemně propojených a od sebe se lišicich znaků a která je inherentně charakterizovaná neustálým posunem na sebe vzájemnè odkazujicích označujicich a odkladem konečného označovaného“. MATONOHA, Jan. Psaní. In Slovnik novějsí literárni teorie: glosár pojmů. Richard Müller - Pavel Šidák (eds.). Praha: Academia, 2012, s. 414.

6 K tomu viz zejm. POLEDŇÁK, Ivan. K některým otázkám Helfertovy estetiky. Hudebni rozhledy, 1957, roč. 10, č. 12, s. 500-502 (výtah diplomní práce K estetickým názorům Vlad. Helferta, 1956); Studie se soustředí hlavně na Helfertův postoj k výrazové estetice konstatujíc, že u Helferta „otázky estetické jsou rěeseny povětšině jen v aplikované podobě v [...] pracích historických a kritických“. Dále viz PEČMAN, Vladimír Helfert, op. cit., s. 94-97; BURJANEK, Josef. Poznámky k estetice Vladimíra Helferta. Hudebni rozhledy, 1975, roč. 28, č. 6, s. 270-273. 
vých let štastně odklonil ze zbloudilé nejedlovské cesty, aby zaujal k Janáčkovi správný - tedy námi dnes široce sdílený - postoj. ${ }^{7}$ Rozhodně pak není mým cílem podat ahistorickou (a takto nutně degradující) „kritiku“ Helfertova muzikologického stylu, jaká se mezi muzikology s oblibou praktikuje v diskusích o Nejedlém. Snažím se pochopit principy Helfertova myšlení a psaní (mezi nimiž je samožrejmě rozdíl), specifický způsob, jímž se dobíral pravdy, abych pochopil, proč dospíval k určitému druhu pro nás dnes mnohdy bizarních výsledků. Pokouším se v posledku popsat a pochopit proměnlivé i poměrně stabilní konceptuální principy, jež umožňovaly Helfertovi specifickým způsobem poznávat Janáčka a jeho hudbu a toto poznání zprostředkovávat.

\section{0-1918: doba „bojů o Dvořáka“ a první světové války}

Až do začátku první světové války - tedy v době svého pražského pobytu, kdy působil v nejedlovském časopisu Smetana ${ }^{8}$ a agilně se zúčastňoval zuřících „bojů o Dvořáka“ Helfert ve svých textech Janáčka v podstatě ignoroval: samostatným článkem nereagoval ani na pražskou premiéru Jeji pastorkyně v roce 1916. Toto v podstatě až útočné ignorování - jež však bylo v kontextu pražského hudebního časopisectví předválečných let obecným jevem ${ }^{9}$ - dokládají zejména ty Helfertovy texty z dané doby, které souhrnně pojednávaly soudobou českou hudbou. Tak např. v roce 1912 Helfert v článku Převrácený kalendár?? uvádí Fibicha, Foerstera a Ostrčila jako zástupce „moderní české zpěvohry“, ale Janáčka ani nezmiňuje. ${ }^{10}$ Podobně o necelý rok později v článku "Jungböhmische Musik“ v obsáhlé úvaze nad soudobou českou hudbou sice pojednává některé nepokrokové skladatele (Kovařovice, Suka a Nováka), ale Janáčka opět úplně ignoruje. ${ }^{11}$

První světová válka výrazně pozměnila podobu hudební kultury v českých zemích, diskursy o hudbě nevyjímajíc. Odtažitý postoj hudební moderny k uměleckému vlastenčení je najednou zapomenut a opět dochází k akcentaci všemožných národnostních hledisek, obnovuje a utužuje se smetanovský kult, předválečné „boje o Dvořáka“ se prizmatem nových skutečností zdají být již poněkud neaktuální, a snad i malicherné.

Za doklad výše řečného můžeme považovat i článek Náš hudebni život ve válce, jejž Helfert publikoval v masarykovském časopisu Naše doba. Výmluvně jej shrnuje následující věta: „Nuže, náš hudebni život vykoná svưj nejvlastnějši kulturni úkol v dnešni naši situaci, bude-li co nejdůrazněji udržovat při životě českou moderní hudbu se Smetanou v čele."12

7 Takovýmto ahistorickým až anachronickým přístupem trpí jinak hodnotná studie BÁRTOVÁ, Jindra. Podivnosti kritických soudů v českém hudebním časopisectví na počátku století. Opus musicum, 1999, roč. 31, č. 4, s. 9-23.

8 Přesto, jak píše Hrabal, „zcela nesdílel a brzy [v letech 1912-1913] opustil Nejedlého jednostranný postoj $k$ našemu posmetanovskému vývoji”. HRABAL, Pohled na Vladimíra Helferta, op. cit., s. 7.

9 BÁRTOVÁ, Podivnosti kritických soudu…, op. cit., s. 20.

10 HELFERT, V. Převrácený kalendář? Smetana, 1911/1912, roč. 2, č. 8/9, s. 132.

11 HELFERT, V. „Jungböhmische Musik“, Smetana, 1912/1913, roč. 3, č. 4/5, s. 48-51.

12 HELFERT, V. Náš hudební život ve válce [...]. Naše doba, 1915, roč. 22, č. ?, s. 268-271. Cit. dle Vladimír Helfert. O Smetanovi: soubor stati a článki̊. Praha: Hudební matice, 1950, s. 72. 
Speciálně pak Helfert píše o nutnosti provozovat českou operu, zejména díla autorů „národni školy operni“ ${ }^{\text {“ }}{ }^{13}$ tedy de facto Smetany a jeho pokračovatelů (Fibicha, Foerstera, Ostrčila a Zicha). Dále uvádí jaksi bokem opery Dvořákovy, Weissovy, Kovařovicovy a konečně také Janáčkovy. Z textu implicitně vyplývá, že i díla těchto autorů by bylo záhodno hrát, ovšem až potom, co bude splacen dluh v podobě děl autorů smetanovských.

V roce 1916 se na stránkách časopisu Smetana Helfert zapojuje do polemiky vzbuzené Nejedlého kritikou Jeji pastorkyně, v níž participovali Štěpán (na straně „protismetanovské“ Hudební revue) a J. Jeremiáš (coby zástupce smetanovské strany) a jež prý byla „vydrážděn[a] Štěpánovým srounáním Pastorkyně se Smetanou, hlavně tvrzením, že Janáček dostal se stejně hluboko ke kořenưm cítěni našeho lidu, jako Smetana". ${ }^{14}$ Nacházíme zde dozvuky vyhrocené, exaltované proti Dvořákovcům zacílené rétoriky z doby „bojů o Dvořáka“. Helfert cituje Jeremiáše:

„... mám obavu, že př̌šti historik při pročítáni referátu dr. Štěpána mohl by si učiniti nesprávnou představu o tom, jak lehce jsme precházeli pres Smetanu k dennimu pořádku [...] porovnáni Smetanova národního významu s významem ,Pastorkyně, obhajování pana Janácka, Smetanova odpurce, který také pomáhal přilévati hořkosti do Smetanova kalicha utrpení, jest hř́ch, zrada a svatokrádež umělecká."

Helfert s Jeremiášovým ostrým výrokem souhlasí a dodává:

„....kdo prožil Smetanu a kdo pochopil jeho nezměrnou velikost [...] nemůže $k$ Janáckovu dílu se postavit jinak, nežli, mírně rěceno, chladně. Nikoliv snad z di̛vodu lidského, nýbrž ryze umëleckého. Nebot’ kdo s naším uměním opravdově žije a komu pokrok a hlavně zdraví našeho moderního uměni hudebniho je životni otázkou, ten nemüže pripustit, aby naše uměni dnešni kleslo pod velkou a vysokou metu Smetanou vztyčenou. To bylo by zpronevěreni dílu Smetanovu. A neni pochyby, že Pastorkyně takový pokles je." 15

Tento článek je prvním textem, v němž Helfert adresně a nesmlouvavě útočí na Janáčka, stavě jej zejména do protivy se Smetanou (implicitně tedy mezi Dvořákovce), podobě jako v té době zhusta činil Nejedlý.

Druhý Helfertův nekompromisní odsudek Janáčka nacházíme o rok později v recenzi koncertu České filharmonie, během nějž premiérově zaznělo Šumařovo ditě. Nacionalistický charakter článku ${ }^{16}$ byl patně podmíněn válečnou situací útlaku českého národa a odpovídal charakteru periodika, v němž byl publikován: silně nacionalistického, subverzivního Národa. Podle Helferta je Šumařovo dítě „pruni čistě orchestrálni dílo Janáckovo, jež právě u nás bylo provedeno"; a "takové dílo, kde [...] skladatel není veden textem, a kde musi

13 Ibid., s. 73-74.

14 HELFERT, V. Jaroslav Jeremiáš: Ad vocem Janáčkova „Pastorkyňa“ a - Smetana. Smetana, 1916/1917, roč. 7 , č. 3 , s. 46.

15 Ibid., s. 47.

16 Helfert píše, že se jedná o koncert z cyklu „ǔeských symfonických koncertů, které v letošní sezoně pořádá komitét českých dam“, v němž „provedena budou díla výlučně českých skladatelů a to řízením českých dirigentů“. HELFERT, Vladimír. České symfonické koncerty. Národ, 1917, roč. 1, č. 34 (22. 11. 1917), s. 609. Kurzíva M. Z. 
uplatnit se pouze jeho hudebnost spojená s básnickou potencí, je nejlepšim zkušebním kamenem [...]. A skutečně, tato orchestrálni práce Janáčova je velmi poučná." Pokračuje takto:

\begin{abstract}
„Mluvi se o Janáčkově primitivismu, v němž spatřuje se hlavni znak svérázu jeho hudby, originalita projevu. ,Šumařovo ditě v̌̌ak ukazuje, že za t. zv. primitivismem skrývá se zpravidla dvoji extrem: bud' raffinovanost, jaká ve zjemnělé, subtilni podobě určuje linii skladeb Debussyových, anebo - chudoba hudebnosti. A tento posledni moment prohlédá skladbami Janáčkovými; aspoň o opaku nedovedla přesvèdčit žádná dosavadni práce Janáčkova. Nevěrim, že by plnokrevný hudebnik, naplněný bohatým fondem hudebnim a lyrickým, byl viibec s to rojici se myšlenky hudebni potlačovat za předem vytknutým cílem primitivismu. To navzájem se vylučuje."
\end{abstract}

Helfert dále ostře kritizuje Janáčkovo pojetí formy, když píše:

\begin{abstract}
„Zpiosob, jakým Janáček nakládá s thematem, jest velice málo hudebni. Je u něho nápadná neschopnost z thematu tvưrči praci něco vyvodit, novou, rozvijejici se myšlenku, novou oblast básnickou. S oblibou uživá malých, hudebně málo cenných, primitivnich motivků, jež s podivnou úporností opakuje tak, že vás jimi př́mo hallucinuje. Tím ovšem vznikla sice délka hudebniho proudu, ale nikoliv forma, která by byla s tvưrčim rozmyslem budována, a která by někam směřovala. ,Šumařovo dítě nemá formy ve smyslu splynuti stavby hudebni s básnickým obsahem. Hudba jeho teče arci bez přetrženi, ale je to pouhé nastavováni proudu, kde sice neni hudebnich censur, ale neni také vnitřni nutnosti, proč skladba neskonči dř̀ve nebo později. "17
\end{abstract}

Zastavme se na chvíli u představy vnitřni nutnosti, široce sdílené estetikou a kritikou 19. století a namnoze přetrvávající i ve století následujícím. Tato představa úzce souvisí s konceptem organického vývoje: kantovský génius tvoří jako příroda, ${ }^{18}$ géniovo dílo se tedy organicky vyvíjí podobně jako živý organismus, a proto musí být právě takové, jaké je. ${ }^{19}$ Představa logické (a organické) formy neodpovídá pouze romantickému hudebnímu ideálu, ale šířeji ideálu jednoty, jenž v 19. století prostupoval většinu, zejména německojazyčných diskurzů o hudbě. ${ }^{20}$

17 Ibid., s. 609-610.

18 KANT, Immanuel. Kritika soudnosti. Praha: Odeon, 1975, s. 125-127 ff.

19 Adler ve své stěžejní práci, kterou Helfert nepochybně dobře znal, píše, že styl jednoho umělce nebo jedné školy či epochy nevyvstává nahodile, ale stojí na zákonitostech vůle, „organického vývoje“ („organischer Entwicklung“). Podobně umělecké dílo je „Organismus“ či „eine Pluralität von Einzelorganismen“. A historický vývoj hudby probíhá podle „vnitřní nutnosti“ („inneren Notwendigkeit“), jíž jsou vnější nahodilosti pouhým efektem. ADLER, Guido. Der Stil in der Musik. I. Buch: Prinzipen und Arten des Musikalischen Stils. Leipzig: Breitkopf \& Härtel, 1911, s. 13.

20 Viz zejm. MAUS, Fred Everett. Concepts of Musical Unity. In Rethinking Music. Nicholas Cook - Mark Everist (eds.). Oxford: Oxford University Press, 2010, s. 172-192. Tento př́stup je však v hudební kritice a analýze mnohem rozšířenější a obecnější; Kerman piše o „archetypal procedure of musical analysis": tento typ analýzy ,takes the masterpiece status of its subject matter as a donnée and then proceeds to lavish its whole attention on the demonstration of its inner coherence". KERMAN, Joseph. How We Got into Analysis, and How to Get Out. Critical Inquiry, 1980, roč. 7, č. 2, s. 313. Pro šíření představy organického vývoje uměleckého díla byl patrně klíčový moment, kdy E. T. A. Hoffmann začal uplatňovat Goethovu koncepci „Urpflanz“ při výkladu velikosti Beethovenovy páté symfonie. Viz tamtéž, s. 315-316 ff. 
V následující větě Helfert v podstatě vysvětluje meritum své tehdejší hudební estetiky, nápadně předjímající strukturalistickou koncepci „sémantického gesta“: „Tajemstvi moderni formy hudebni spočívá v tom, že dílo má určitý centrální bod ideový, v němž básnická myšlenka nacházi svi̊j smysl, a $k$ němuž směřuje celý hudebni proud. Tím forma sebe volnějši zachycena je určitým jednoticím principem básnickým a hudebním. "Tomuto Helfertovu ideálu se však Janáčkova hudba ani zdaleka nepřibližuje: „Při nasloucháni máte dojem, že obracíte ilustrovanou knižku, list za listem, s neměnici se jednotvárností, a skončíte tuto neutěšenou práci kdy je libo. Hudebni chudoba spojena zde s nedostatkem formálni nutnosti a hudebně-logického a básnického děje." 21

Shrňme nyní vlastnosti, které v této důležité recenzi Helfert přisuzuje Janáčkovi a jeho hudbě. Tou hlavní je primitivismus - v něm spočívá Janáčkova inherentni svéráznost a originalita, jež je naprostá a nekompromisní, projevující se proto vždy a všude. Janáček je skladatel chudé hudebnosti, musí se proto opírat o text. V jeho hudbě se projevuje nedostatečná ,formálni nutnost", hudební logika a básnická dějovost, jež Janáček nahrazuje př́iznačnou repetitivností, skládaje svou hudbu z malých motivků a do zprotivení je omílaje.

Ve své zásadní publikaci z přelomového období, epištole Naše hudba a český stát, vydané v únoru 1918,22 Helfert rekapituluje úspěchy a význam české posmetanovské hudby. Zajímavé je, že už v této své koncepci moderní české hudby Helfert harmonizuje protikladné strany Nejedlého koncepce, tedy uznává Dvořáka i jeho žáky řadě je mezi „bohatou žeñ “ české hudby, ba co víc, pojímá je všechny coby sourostlé $\mathrm{z}$ „požehnaného semene Smetanova“. ${ }^{23}$ A Janáček? Toho v této eseji, dokonce ani v jejím závěru pojednávajícím o situaci v Brně a na Moravě, slovem nezmiňuje: dva roky poté, co skladatel nastoupil svou celosvětově úspěšnou cestu...

Přestože, jak naznačuje Hons, ${ }^{24} \mathrm{v}$ roce 1917 došlo k zásadní proměně Helfertova muzikologického myšlení, jeho postoj k Janáčkovi se zatím patrně nezměnil. Helfert v té době spolu s Nejedlým a dalšími kritiky sdruženými okolo časopisu Smetana patřil mezi hlavní Janáčkovy odpůrce, i není tedy divu, že právě tehdy Janáček v jednom ze svých fejetonů napsal - ovšem s ironickou nadsázkou - o svém „,hrozném strachu před nejedlým Helfertem“ “.25

\section{9-1925: v nové situaci}

Konec války a vznik republiky otevírají další etapu Helfertova muzikologického vývoje. Obecně se má za to, že Helfertův příchod do Brna v létě 1919 znamenal počátek zásadní

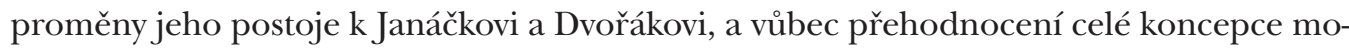
derní české hudby. Podívejme se tedy podrobněji, jak se tato proměna promítla do Helfertových janáčkovských textů.

21 HELFERT, České symfonické koncerty, op. cit., s. 610.

22 VYSLOUŽIL, Jiří. Léta brněnského působení Vladimíra Helferta. Opus musicum, 1975, roč. 7, č. 10, s. 293.

23 HELFERT, V. Naše hudba a český stát. Praha: B. Kočí, 1918, s. 3.

24 Studie Motiv Smetanova Vyšehradu z roku 1917 „prezentuje Helferta již zcela jinak, jako muzikologa oproštěného od ideologických předpojatosti a zaměreného na věcnou podstatu tématu“. HONS, Boj o českou..., op. cit., s. 41-42.

25 JANÁČEK, Leoš. Výlety páně Broučkovy. Lidové noviny, 1917, roč. 25, č. 351 (23. 12. 1917), s. 1. 
V březnu 1920, krátce po svém přesunu do Brna, Helfert referoval o premiéře Balady blanické. Stejně jako Šumařovo dítě, předchozí Janáčkova skladba, kterou Helfert recenzoval (1918, viz výše), je i Balada blanická symfonickou básní. Tato skutečnost je pro nás důležitá, nebot srovnání dvou Helfertových hodnocení Janáčkových výtvorů v oblasti typicky novoromantického žánru mủže nad jiné lépe ukázat př́ípadnou proměnu Helfertova celkového pojímání Janáčka: proměnu, jež se udála během pouhých dvou let.

V recenzi Balady blanicke $e^{26}$ Helfert s náznakem uznání zdůrazňuje Janáčkovu originalitu:

„Janáček má určitý, ostře vyhraněný typ ve svém hudebním vyjadřováni. I když máte $k$ hudbě L. Janácka jakékoliv subjektivni stanovisko, vždy musíte s respektem uznati důslednost, s jakou jde za svými cíly [sic] a v důsledku toho je pregnantni individualita, jakož $i$ to, že Janáček v každém svém novém dile přinese něco nového, nikoho nemůže nechati lhostejným. Rozhodně patř́ $k$ těm umèlcưm, kteři nespokojili se pohodlnou drahou uměleckou, nýbrž kteři razili si své vlastní cesty. " ${ }^{27}$

Pokračuje důležitým konstatováním: „Jeho symfonická báseň [...] ukazuje základni rys Janáckovy umèlecké individuality: jeho zvláštni a tak charakteristickou aforističnost. Janáček ve suých literárnich projevech vyjadřuje se nejraději krátkými, často úsečnými aforismy. Tento charakter má $i$ jeho hudba." Před dvěma roky psal Helfert o primitivnosti coby hlavní vlastnosti Janáčkovy hudby (a implicitně též Janáčka samého), a nyní o - aforističnosti. Míní tím vlastně totéž, ale mění se perspektiva: co bylo nahlíženo jako negativní zaostalost, stává se pozitivním rysem. Ponechme stranou, že Helfertův vkus tehdy setrvával (použijeme-li jeho oblíbenou metaforu) „v poutech tradice“ romantického hudebního ideálu, založeného na vyklenutých melodických obloucích, komplikované motivicko-tematické a kontrapunktické práci apod. ${ }^{28}$ At̉ už se jeho vkus později změní či nikoliv, Helfert bude tento Janáčkủv anti-romantismus ve svých textech po roce 1919 čím dál více uznávat jako kvalitu sui generis. Helfert ztotožňuje charakter hudby s charakterem jejího tvůrce: ona aforističnost je nejen základním rysem Janáčkovy hudby, ale též bytostným rysem Janáčka samého: proto se projevuje i v Janáčkově literární tvorbě. ${ }^{29} \mathrm{~V}$ recenzi Šumařova dítěte Helfert Janáčkovi ostře vyčítal nedostatek formy, logičnosti, vnitřní nutnosti, atp.; naproti tomu v o dva roky mladší recenzi Balady blanické píše:

„Také na novém dile Janáckově tento základni rys [aforističnost] zanechal své stopy, hlavně na formálni stavbě. Blanické rytî́re staví, jako obvykle, z motivư krátkých, úsečných a toutéż úsečností vyznačuje se celková forma nového díla, takže zapomeneme-li na tento individuelní znak Janáckưv, jsme překvapeni neočekávaně brzkým závěrem. Jakoby ani v hudbě nebyl př́telem dlouhých řeči." 30

26 Uvedené pod názvem „Blaničtí rytîríi“.

27 HELFERT, V. Brněnská konservatoř. Socialistická budoucnost, 1920, roč. 18, č. 72 (28. 3. 1920), s. 1. Zvýraznil M. Z.

28 Podle Bártové Helfert „nejvýše cení [...] vždy ty autory, u nichž mưže konstatovat lineární myšleni“. BÁRTOVÁ, Postoje Vladimíra Helferta k českým skladatelům po Bedřichu Smetanovi. Opus musicum, 1986, roč. 18, č. 6, s. 165 .

29 Tuto tezi pak Helfert rozvádí v samostatné studii Janáček - čtenář z roku 1928.

30 HELFERT, Brněnská konservatoř, op. cit., s. 1. 
Důraz na „formálni nutnost“ a „hudebnělogický a básnický děj“ mizí, a Helfert se v této recenzi zásadně odklání od romantického hudebního ideálu: dokonce ani v případě symfonické básně jej nezajímá hudební traktace děje. Místo toho se soustředí na samotnou radikální novost, originalitu hudebního vyjadřování a v nemenší míře na neústupnost, $\mathrm{s}$ jakou za nimi Janáček postupuje přinášeje v každém díle něco nového. Tyto vlastnosti se nacházely (třebaže jinak pojmenované) už v předchozí recenzi, zde ovšem povýšily: staly se hlavními kvalitami Janáčkovy tvorby. Pohled’me na další transformace Helfertova psaní. „Čistě hudebně jest př́značný pro novou symfonickou báseň ryze janáčkovský ruch a často dravost hudebniho proudu, která působi často dojmem elementární síly.“ 31 Tedy: „primitivismus“ se mění v „elementární sílu“, a ta je uznána za základní janáčkovskou kvalitu.

Tuto recenzi považuji z hlediska vývoje Helfertova psaní o Janáčkovi za zvlášt důležitou zejména ze dvou důvodů. Jednak zde Helfert Janáčka poprvé hodnotí kladně, i když ještě poněkud opatrně, jednak zde nacházíme zárodky některých strukturních konstant Helfertovy koncepce Janáčka, jež se budou od nynějška dále rozvíjet.

Na pražskou premiéru Výletů páně Broučkových v dubnu 1920 a dokonce ani na brněnskou premiéru Káti Kabanové v listopadu 1921 Helfert nijak nereagoval, a nereflektoval ani brněnskou premiéru Zápisniku zmizelého a Tarase Bulby v témže roce. 26. dubna 1922 pak vyšla v Moravských novinách jeho recenze „večera moravských hudebních novinek“, v jehož rámci premiérově zazněla Janáčkova houslová sonáta. Nová skladba má podle Helferta

„všechny znaky Janáčkovy tvorby, které se projevuji v Tarras Bulbovi, v Káti a také již v Pastorkyni. Překotná dravost, spojená s náruživou citovostí [...]. V prvni větě zevni rámec $t$. zu. sonátové formy jest ponèkud tísnivým poutem pro elementárni hudebni projev, který co chvili jako v plamen vyšlehne, aby zase - po zprisobu ryze janáckovském - ustoupil trhaným, bleskurychlým pasážím. [...] Tato sonáta patř́ k tèm dílům Janáčkovým, které si vynucuji úctu silou své individuál. I když s četnými stránkami jejimi nedovedete se smiriti. “"

Jak vidíme, Janáček coby autor v Helfertově diskurzu funguje jako jednotící instance, jejíž charakteristiky se projevují ve všech jejích dílech: individuálnost, elementárnost, prudká vášnivost, trhavá dravost... Dříve Helfert Janáčkovi vyčítal nedostatek formovosti, nyní by se podle něj měl Janáček tradiční formy úplně zříct, nebot jej svazuje. ${ }^{33}$

Potom píše o Janáčkovi až na podzim roku 1924 při př́ležitosti skladatelových jubilejních oslav, v jejichž rámci bylo v Brně prezentováno takřka celé dosavadní Janáčkovo dílo. Proberme se tímto důležitým textem postupně, po jednotlivých koncertech.

V recenzi sborového koncertu, konaného 11. ř́ijna, Helfert píše:

„Dež vís a Klekanica ukazuji již Janáčkovy rysy. Hlási se nový typ vokálni melodie a prípravuji se některé deklamačni složky potomního slohu Janáčkova [...]. Je ale při tom zajimavo, že oba tyto sbory, jež

31 Ibid.

32 HELFERT, V. Koncerty. Moravské noviny, roč. 43, č. 95 (26. 4. 1922), s. 1.

33 Z recenze mimo jiné vyplývá, že Helfert do roku 1922 Tarase Bulbu a Kátu Kabanovou (jejichž uvedení nerecenzoval) bud' slyšel, nebo je přinejmenším znal z partitury. 
vznikly až po Pastorkyni, nemaji, u porovnáni s Pastorkyni, tak ostře vyvinutých rysů individuelních. Janáčkův styl byl dříve vyhraněn v opeře, nežli ve sborech $a$ již z toho di̛vodu by bylo třeba poznati operni jeho dila před Pastorkyni. Teprve Kantor Halfar [...] ohlašuje již nový styl sborový a Maryčka znamená plné jeho vítězstvi."

Sbory Sedmdesát tisíc a Česká legie Helfert pouze zmiňuje, ale nekomentuje. Novinka, mužský sbor Potulný šilenec, podle něj „svým prudkým dramatickým spádem, pevnou linii a sugestivností výrazu patři $k$ nejlepšim našim sborovým výtvorům a je svědectvím neúnavné průbojnosti Janáčkovy inspirace“. ${ }^{34}$

Následoval koncert kantátový (19. října), sestávající z Otčenáše, Amara, Na Soláni Čarták a Vě́ného evangelia. Na Helferta zanechal „nejhlubši dojem“ Amarus, nebot Vrchlického text „inspiroval Janáčka k tónům plným hlubokého soucitu a tragiky. Bude se vždy řaditi $k$ největšim výtvorům Janáčkovým". ${ }^{35}$ Jak ještě uvidíme, pro Amara bude mít Helfert slabost i nadále. Ke čtvrté skladbě, Otčenáši, se Helfert nijak nevyjádřil.

V recenzi dalšího koncertu (21. října), představujícího Janáčkovu klavírní a komorní hudbu, se Helfert zastavuje pouze u premiérovaného dechového sextetu Mládí, jenž "oplývá bytostným humorem a jiskrnými hudebnimi nápady“. ${ }^{36}$ Ostatní skladby (oba klavírní cykly, houslovou sonátu, Pohádku a Lidová nokturna) ignoruje.

V posudku inscenací oper Př́hody lišky Bystroušky, Jeji pastorkyňa a Kát’a Kabanová se Helfert soustředil na první z nich, jež zde zazněla premiérově. Napsal:

„Hudebně je nové dilo svědectvím obdivuhodné tvưrči svěžesti Janáčkovy. Zdramatisováni zviřrecího světa vyvolalo nové tóny a nové instrumentálni vymoženosti, jakých jsme dosud nebyli svědky u Janáčka. Partitura je bohatá jemně a bystře zachycovanými barvami, elementární rytmika doplňuje se zde s melodikou, která jest zde poněkud rozvinutější, nežli jsme zuykli u Janáčka. Jsou zde delši partie (svitáni, milostné sceny lišky a lišáka, závěr revírnikưv), v nichž hudba se rozezpívá v bohaté květy melodické a ve velkou vřelost. Jsou také mista, kde zachycováni těkavých dojmů dává hudbě známou rapsodičnost Janáčkovu. Celek je hudebně spiat v jedno pásmo, jež je stavěno bez rušivých cesur. Bystrouška je po hudebni stránce dílo nové a průbojné.“

\section{Obzvlášt zajímavé jsou Helfertovy výtky:}

„Dramaticky však trpi látkou. Děj je př́liš nejednotný, nezkoncentrovaný. Současné postaveni svèta lidského a zvírecího na sceně vrhá své stíny nejen na scenický obraz, nýbrž i na celé dílo. Episodičnost lidských figur pưsobi nejednotně a bylo by jen v zájmu dila, kdyby tyto lidské figury byly odstraněny, a kdyby z díla stala se opera pouze ze světa zviřecího. Pak by geniální a svěží hudba prišla lépe $k$ platnosti. Postava revirnikova mohla by při tom zưstati, a to v prologu a epilogu. Tím by také se ziskalo větši koncentrace na postavu Bystroušky. Že by tím nejuětši potiž režijni byla odstraněna, je rovněž jasno. " 37

34 HELFERT, V. Janáčkovy oslavy v Brně. Hudebni rozhledy, 1924/1925, roč. 1, č. 3/4, s. 66-67.

35 Ibid., s. 67.

36 Ibid., s. 67-68.

37 Ibid., s. 68. Zvýraznil M. Z. 
Janáčkovské jubilejní oslavy v roce 1924 můžeme chápat jako zásadní impuls, nebot právě po nich začal Helfert hojněji a systematičtěji psát o Janáčkovi a jeho hudbě. Vysvětlení je nasnadě: prostřednictvím slavností se Helfert podrobně seznámil s Janáčkovou tvorbou, což mu umožnilo v ní samotné spatřit onu tak žádoucí vývojovou logiku a zároveň ji vřadit do vývoje moderní české hudby. Zde poprvé explicitně píše o Janáčkovi coby géniovi, a slovo „individualita“ se odted’ bude v Helfertových janáčkovských textech pořád opakovat.

Zanedlouho po janáčkovském festivalu Helfert publikoval v prvním ročníku jím založeného časopisu Hudební rozhledy na pokračování svou vůbec první janáčkovskou studii - Janáčkovy neznámé opery. Zde již klade Janáčka do vývojové souvislosti české hudby, po bok Smetany, Dvořáka a Fibicha. Šárku považuje za přelomové dílo v dějinách české hudby a v poměrně rozsáhlé analýze o ní píše jako o logickém pokračování tragické linie české operní tvorby. ${ }^{38}$ Za nejvýznačnější vlastnosti Janáčkovy umělecké osobnosti pokládá „sklon $k$ realismu a bezprostřednosti vnitřniho života“, opakovaně zdůrazňuje, že Janáček je „nový typ skladatelský. Logiku Janáčkova uměleckého vývoje si utvrzuje seznámením se s operami Počatek románu a Osud, přičemž druhou z nich hodnotí podobně vysoce jako Šárku.

Helfertův zvýšený pozitivní zájem o Janáčka dokumentuje skutečnost, že v listopadu 1924 inicioval vydání janáčkovského dvojčísla Hudebních rozhledů k mistrovu životnímu jubileu. ${ }^{39}$

V téže době, v letech 1924-1925, se na stránkách Hudebních rozhledů Helfert kriticky vymezil vůči první janáčkovské monografii, jejímž autorem byl, jak známo, Max Brod. ${ }^{40}$ Také polemizoval s K. B. Jirákem háje specifickou kvalitu moravské hudby (v čele s Janáčkem) a odmítaje Jirákovo tvrzení o existenci moravského separatismu v hudbě ${ }^{41}$ a brojil proti neadekvátní, výrazově-estetické kritice Janáčkovy klavírní sonáty. ${ }^{42}$ Ve zmíněném článku o moravské, potažmo brněnské „svojskosti“ zcela tainovsky tvrdí, že brněnské, od pražského výrazně odlišné kulturní klima „organicky a di̊sledně roste z povahové odchylky zdejšiho obyvatelstva $i$ z historických predpokladï“.

Od roku 1925 Helfert hojně psal o Janáčkovi na stránkách nově vzniknuvšího socialistického deníku Ruch. Kladně se zde vyjadřuje o Lašských tancich ${ }^{43}$ nadšeně referuje o premiérovém provedení Šárky. ${ }^{44} \mathrm{~V}$ eseji $O$ Zdenka Fibicha opět klade Janáčka (konkrétně jeho opery Šárka a Jeji pastorkyňa) po bok nejvýznamnějších zjevů české posmetanovské hudby - Foerstera, Zicha, Fibicha a Ostrčila, tedy již v podstatě mezi klasiky. ${ }^{45}$ Fibicha srovnává

38 Využité pak v torzu janáčkovské monografie z roku 1939.

39 Podle Majera v roce 1924, tedy v době, kdy začínaly vycházet Hudební rozhledy, Helfert zásadně přehodnotil svůj hudební kriticismus ve smyslu „odklonu od romantického názoru na hudbu“. MAJER, Jiří. Vklad hudebnímu časopisectví. Opus musicum, 1975, roč. 7, č. 10, s. 299.

40 HELFERT, V. Max Brod: Leoš Janáček, život a dílo. Hudebni rozhledy, 1924/1925, roč. 1, č. 3/4, s. 71-72.

41 HELFERT, V. Moravská a pražská „svojskost“. Hudebni rozhledy, 1924/1925, roč. 1, č. 5, s. 90.

42 [HELFERT, V.?]. Kriteria. Hudebni rozhledy, 1924/1925, roč. 1, č. 5, s. 90.

43 HELFERT, V. Opera v Brně. Ruch, 1925, roč. 1, č. 42 (21. 2. 1925), s. 2.

44 HELFERT, V. Opera Národního divadla. Ruch, 1925, roč. 1, č. 258 (13. 11. 1925), s. 1-2.

45 HELFERT, V. O Zdenka Fibicha. Hudebni rozhledy, 1925/1926, roč. 2, č. 3-4, s. 37-40. Cit. dle Vladimír 
s generačně spřízněným Janáčkem a klade je jako dva protipóly: „snivý romantik“ versus „prudký, výbojný realista“. ${ }^{46}$ Tím spíše nás ale zaráží, že Janáčka vůbec nezmínil v přehledovém článku souhrnně pojednávajícím teoretické bádání na poli lidové hudby. ${ }^{47}$

\section{Helfertova koncepce Janáčka}

Stěžejním Helfertovým textem z tohoto zlomového období let 1924-1925 je, kromě zmíněných Janáčkových neznámých oper, studie Umělecká osobnost Leoše Janáčka, v níž se poprvé pokusil o celistvé uchopení fenoménu Janáček. V těchto dvou textech krystalizuje Helfertova koncepce Janáčka. ${ }^{48}$ Od té doby až do své smrti ji bude výrazně rozvíjet a upřesňovat, a tento proces vyvrcholí v České moderni hudbě. Její základní struktura - a to je třeba zdůraznit - se však stabilizovala nejpozději v roce 1925. Uvedu zde nyní heslovitě její základní rysy.

(1) Organicismus. Helfert vřazuje Janáčka do organického vývoje moderní české hudby a zároveň pojímá samotný Janáčkův umělecký vývoj jakožto vývoj organický. Organičnost a logika vývoje celkové Janáčkovy tvorby Helfertovi nahrazuje vnitřní konstruktivnost, koherenci a logiku většiny Janáčkových děl. Zároveň se Janáčkova tvorba už prostřednictvím první opery, Šárky, stává stadiem organického vývoje celé moderní české hudby, již však Helfert v polovině dvacátých let chápe už podstatně šířji než Nejedlý: moravského mistra klade zcela samozřejmě po bok klasiků české moderní hudby, Smetany, Dvořáka a Fibicha. Šárku považuje za přelomové dílo v dějinách české hudby a píše o ní (jako už dříve) coby o logickém pokračování tragické linie české operní tvorby; na ni pak organicky navazuje Jeji pastorkyně, „dilo nově pojatého a nově řě̌eného tragismu“. Zvláště nápadná a pozoruhodná je Helfertova tendence naroubovat Janáčka na Smetanu: přesvědčit čtenáře, že Janáček je silnou větví stromu kořenícího ve Smetanovi. Podmínkou takovéhoto nahlížení Janáčkovy tvorby se pro Helferta stává právě poznání skladatelových operních děl před Pastorkyni, zejména Šárky. ${ }^{49}$

Helfert. O české hudbě. Praha: SNKLHU, 1957, s. 100.

46 Ibid., s. 102.

47 Helfert zde naopak opakovaně zmiňuje Hostinského, ale také Zicha a dokonce A. Hábu. HELFERT, V. K otázce našeho hudebního folkloru. Morava, 1925, roč. 1, č. 8, s. 230-236. Podobně zarážející je fakt, že nenî Janáček ani slovem zmíněn v této o rok mladší studii (mimochodem z téhož časopisu): HELFERT, V. P. Kř́ǐ̌kovský a B. Smetana. Morava, 1926, roč. 2, č. 6, s. 161-174.

48 Není snad náhodou, že právě v té době Helfert publikoval výzvu k obratu v muzikologickém a hudebně-kritickém myšlení a přehodnocení dogmatického pohledu na moderní českou hudbu. Viz HELFERT, V. Čeho je potřeba. Hudebni rozhledy, 1924-1925, roč. 1, č. 1-2, s. 1-4.

49 „Uvědomíme-li si, že Janáčék ve svém zpěvoherním slohu vyšel z díla tak zákonitě a logicky budovaného, kde vnitřní architektonika jde ruku v ruce s dramatickým životem, pak nutně budeme na dalši vývoj Janáčkưv pohlížeti jinak, než se dosud namnoze dálo, nemálo $i$ vinou toho, že z děl před Pastorkyni nebylo nic známo. Pak stylové novoty v Pastorkyni nebudou moci býti považovány za schválnosti, experimenty, nebo dokonce neschopnost vytvořiti pásmo na základě pevné motivické práce. Ke stylu Pastorkyně dospèl Janáček cestou dalšího vývoje. “ HELFERT, V. Janáčkovy neznámé opery. Hudební rozhledy, 1924-1925, roč. 1, č. 3-4, s. 48-55. Cit. dle Vladimír Helfert. OJanáčkovi. Soubor statí a článků. Praha: Hudební matice Umělecké besedy, 1949, s. 37. 
(2) Helfert staví do kontrapozice Janáčka a jiné velikány moderní české hudby a zobrazuje Janáčka jako naprostou individualitu: zdůrazňuje jedinečnost jeho osobnosti, jeho hudby i jeho osudu. Helfert často ukazuje Janáčkova specifika na základě kladení jej do protivy se Smetanou, Fibichem, Novákem, a vůbec všemi stylově „staršími“ generacemi českých skladatelů. ${ }^{50}$ Tato kontrapozice probíhá i později hlavně ve smyslu Janáček vs. klasicismus (Smetana), potažmo romantismus (Fibich), či Janáček vs. intelektualismus a konstruktivismus (Novák, Petrželka aj.). Ze „starších“ skladatelo̊ Janáček vyrůstá, na druhou stranu ale, coby jedinečný charakter, nemá v české hudbě předchůdce. Zároveň však - a zde je Helfert dialektikem (srov. bod č. 1) - pojímá sumu zmíněných osobností moderní české hudby jako geneticky provázanou unitas multiplex.

(3) Uznání některých negativ Janáčkova hudebního myšlení jako specifických kvalit. Těmito novými kvalitami jsou zejména ne-konstruktivnost, aforističnost, rapsodičnost, těkavost, elementárnost, rytmická uvolněnost. Helfert si všímá též typického jevu, který Janáček praktikuje a současně teoretizuje („ک̌̌časování“ či „sčasovky“), když píše o „vplétáni drobných, srázných figurek rytmických do jinak klidného pásma hudebního, čimž proniká sem stálé zneklidněni". ${ }^{51}$ Nuže, Janáčkova hudební řeč je podle Helferta asi taková:

„...krátké motivky, z nichž daleko nejuětš́ část je rytmicky i metricky úsečná, bystrá, srázná. Jen ten dynamism spojuje tyto hudebni aforismy v jeden prudký tok. Proto tvorba Janáckova nemá konstruktivní monumentality ve smyslu monumentality klasicismu. Konstrukce organismu je mu protismyslná, nebot' se nesrovnává s jeho absolutním požadavkem exprese. Této typicky expresionistické povaze umělecké jest př́značná zkratka uměleckého výrazu. Zkratka a stručnost stávaji se charakteristickými znaky jeho díla. Je v tom opět něco, co ve své době bylo velmi nečasové a co nyni se pocituje jako něco, co vyhovuje potřebám dneška." ${ }^{52}$

Helfert zobrazuje Janáčka jako génia, jako divoký živel, jehož tvorba přímo vytryskává z inspirace bez racionálního korektivu. Přesto však nikdy neopomene naznačit, že Janáčkův odklon od konstruktivní hudební práce je snad až přehnaný: důležité však je, že Helfert tento extrémní přístup respektuje coby přístup originální. Originalitu hudebního myšlení a jeho vývojovou logiku (viz bod č. 1) formuloval Helfert ve svých univerzitních přednáškách explicitně jako „zavazujici fakta [...] hodnoty“ skladatelského „zjevu“.53

(4) Janáček jako zcela nový, revoluční typ skladatele, plně odpovídající nové době a přinášející ve svých dílech vždy něco nového: bytostný experimentátor: „...po celou dobu své tvorby, až do dneška, má nesmiřitelný a často nespravedlivý odpor proti tradici. Nenávidí,

50 „Fibich, typický a čistokrevný romantik, zdá se dnes patřiti k době, která své posláni již splnila. Naproti tomu umění Janáčkovo cítime stále jako cosi živého, jež přináši nové problémy. [...] A přece byl Fibich pouze o 4 leta starší! Tedy chronologicky patři Janáček - dnes se to zdá až neuveřitelné - do stejné generace s Fibichem! A přece jako by mezi nimi byla doba celé generace!"Ibid., s. 39.

51 Ibid., s. 36.

52 HELFERT, V. Umělecké osobnost Leoše Janáčka. Národni a Stavovské divadlo, 1925, roč. 2 , č. 36 (9. 5. 1925). Cit. dle Helfert, O Janáćkovi, op. cit., s. 57.

53 Rkp. Helfertových přednášek „Základy hudební kritiky“, jež držel ve škol. r. 1924/25 a 1929/30. Cit. dle BLAHYNKA, Miloslav. Pojetí teorie kritiky u Vladimíra Helferta. In Vladimír Helfert v českém..., op. cit., s. 90. 
zajisté právem, vše konvenční. Ale stejně odmítá vývojovou kontinuitu. Je prudký revolučni rys $v$ této povaze a to především dodává jeho zjevu tak mladistvého rázu. " ${ }^{54}$ Helfert zdơrazňuje především novost „hudebně-dramatického myšleni“, ${ }^{55}$ což zase odpovídá jeho chápání Janáčka coby skladatele primárně hudebně-dramatického a vokálního (viz bod č. 6).

(5) Identita charakteru Janáčkovy osobnosti a charakteru Janáčkovy hudby. Helfert tuto představu lapidárně vyjádřil slovy: „...protože Janáček je typ jedinečně silného, průbojného, neklidného a výbušného temperamentu [...], je tím současně dán základni charakter jeho umělecké osobnosti. “56 Dále tento koncept rozvádí např. v následujícím citátu:

\begin{abstract}
"Je mnoho rapsodického a aforistického v jeho umèlecké povaze. Všechny jeho dosavadni projevy ukazuji, že tento rys patři $k$ základním znakưm celé jeho individuality. Jeho četné literárni projevy i jeho přednášky a zpơsob řeči projevuji týž základni charakter: nikdy nerozvine své myšlenky soustavně. Vždy ji jen aforisticky hodí na papir, naznači a vyslovi v nejzkrácenější formě, co nejzhuštěněji. Jeho fejetony i studie jsou vždy řadou těchto bystrých, úsečných gloss. " ${ }^{\text {rj7 }}$
\end{abstract}

Pohled'me pro srovnání a coby důkaz neustále přítomného vlivu duchovědného myšlení, co napsal Dilthey o Goethovi:

\begin{abstract}
„Seine Stimmungen schaffen alles Wirkliche um, seine Leidenschaften steigern Bedeutung und Gestalt von Situationen und Dingen ins Ungemeine, und sein rastloser Gestaltungsdrang wandelt alles um sich in Form und Gebilde. Sein Leben und seine Dichtung sind hierin nicht unterschieden, seine Briefe zeigen diese Eigenschaften gerade so wie seine Gedichte. ${ }^{\text {"58 }}$
\end{abstract}

Helfert buduje svůj výklad vycházeje z představy podmíněnosti Janáčkova charakteru, a tím i charakteru jeho hudby, rasou a prostředím. Tato představa, evidentně ovlivněná tainovskou materialisticky-pozitivistickou koncepcí, se výrazně projevila též v Helfertově smetanovské monografii z roku $1924^{59}$ a v textech Zdeňka Nejedlého. ${ }^{60}$ Helfert líčí

54 „Nenávidi tradičních forem. Inspirace, jakožto okamžitý výraz nitra určuje si svou formu a jest sama pravou formou. Proto hudebni myšlenka, motiv, jest mu něco ojedinělého, typického, pro určitou chvíli, určitou scénu a nelze s ním pracovat ve smyslu motivistické práce klasicismu, nebot’ tím se porušuje zákon výraznosti. Tak věrí Janáček! Ve své tvorbě odklánèl se stále více od $t$. zu. thematické práce. Hybnou silou jeho dèl stává se živelný dynamism a nikoliv motivická souvislost. V této věci Janáčkova tvưrči methoda byla něčím zcela novým v době, která byla zuyklá na wagnerovský princip přiznačných motivĩ. Proto opera, Pastorkyña' nemohla najiti hned porozuměni. Jeho exponováni myšlenky je zcela individuální; neboji se - žádá-li toho situace - opakovati motiv za cenu nebezpečí, že tím unavi. "HELFERT, Umělecké osobnost..., op. cit., s. 56.

55 HELFERT, Janáčkovy neznámé opery, op. cit., s. 28.

56 Ibid.

57 Ibid., s. 57.

58 DILTHEY, Wilhelm. Das Erlebnis und die Dichtung: Lessing, Goethe, Novalis, Hölderlin. Vyd. 8. Leipzig und Berlin: Verlag B. G. Teubner, 1922, s. 179.

59 HELfERT, V. Touirči rozvoj Bedřicha Smetany. I. Preludium k životnímu dilu. Praha: Jos. R. Vilímek, 1924, zejm. s. 12-15.

60 Srov. ZAPLETAL, Miloš. From Tragedy to Romance, from Positivism to Myth: Nejedlýs Conception of the History of Modern Czech Music. In: Nationality vs. Universality: Musical Historiographies in Central and Eastern Europe. Sławomira Żerańska-Kominek (ed.) Cambridge: Cambridge Scholars Publishing, 2016, s. 99-124. 
faktory podmiňující charakter autorovy tvorby přísně deterministicky v podobě kauzálního řetězce (nebo pyramidy): prostředí - povaha lidu - povaha umělce - povaha jeho díla.

(6) Janáček jako primárně vokální a dramatický skladatel. Helfert dokazuje Janáčkovu velikost a vývojovou logiku nejprve na příkladu jeho prvních dvou oper, Šárky a Osu$d u$, a též v dalších textech jej traktuje v tomto smyslu. Ve studii Umělecká osobnost Leoše Janáčka už pojednává všechny Janáčkovy opery do Lišky Bystroušky (včetně). Co se týče Janáčkovy vokální hudby, píše:

\begin{abstract}
„Vedle uvedených znakư jeho osobnosti je hlavním zdrojem jeho dila mluvená řeč, jeji skutečné a latentni intervaly a jeji přirozená rytmika[.] Janáček oddal se s láskou studiu řeč po této melodické a rytmické stránce a vyváżil odtud nové a netušené obohaceni svého hudebního výrazu. Proto také vokálni melodie jeho dèl má zcela nový, individuálni charakter. Janáček v mluvené rèč zachycuje drobné, stručné a srázné motivky a na nich docházi k vytřibeni své methody výrazové zkratky. Proto také jeho vokálni melodie se pohybuji ve hbitém, prudkém rytmu a v nezvyklých intervalech."
\end{abstract}

K dramatismu pak píše:

"Janáčki̛v výrazový princip tvůrčí, útočnost jeho inspirace, dravý dynamism jeho hudby ženou jeho tvưrči výboje $k$ dramatickému vyostrováni. Ostré dramatické hroty jsou v organické a nutné souvislosti s celou jeho osobností. I do drobných vět klavirnich proniká tento zneklidňujici element, jenž co chvili zčeři zdánlivě klidnou hladinu nečekaným vírem. Nejúčinněji ale zasáhl tento element do děl vokálních. [...] Zde možnost okamžitého výrazu, spojeného s novou vokálni melodii, dávaly přirozeně nejlepši podminky. A tak Janáček se stává mistrem sborové tvorby; vedle Smetany, J. B. Foerstera a Vit. Nováka vytuář́ nový typ sborové skladby, kde prudké zdramatisováni formy sborové jej privedlo $k$ novým formovým útvarưm, $k$ nebývalému uvolnèni a zindividualisování jednotlivých hlasů a $k$ novým melodickým a tedy $i$ výrazovým možnostem tohoto útvaru, jenž jest tak typický pro moderni českou hudbu [...]. Že Janáček ze zminěných disposic byl celou svou povahou vehnán do operni tvorby a že v důsledku celé své osobnosti zde musel vytvořiti individuálni typ, stalo se nutným di̊sledkem vývojovým a psychologickým. Těžiště uměleckého významu Janáčkova jest v jeho dílech dramatických. "61

I zde vidíme, jak se jednotlivé části Helfertovy koncepce vzájemně provazují a podmiňují.

(7) Janáček jako trpící, s osudem a světem bojující, ano beethovenovský génius. Helfert čím dál více buduje svůj výklad Janáčkova života (podmiňující jeho dílo) na líčení křivd, které musel snášet, a tragičnosti jeho života uměleckého i osobního, plného bolesti a zneuznání - velmi podobně Helfert (a také Zdeněk Nejedlý) líčí skladatele ze svého pohledu absolutního: Smetanu. Svůj výklad však nepojímá jako tragédii, nýbrž jako romanci: Janáček zvítězil, překonal všechny překážky. ${ }^{62}$

(8) Helfert rozvíjí mýtus věčně mladého Janáčka, vyskytující se hojně v diskurzech o Janáčkovi, tím hojněji, čím se Janáček stával po roce 1918 uznávanějším (až kultovním

61 HELFERT, Umělecké osobnost..., op. cit., s. 57-58.

62 Srov. ZAPLETAL, From Tragedy to Romance, op. cit., s. 114-121. 
či oficiálním) umělcem. Píše o jeho vitalitě a „naturálním temperamentu“, projevujících se samozřejmě též v jeho hudbě: „Mladý stařec, stále nespokojený, stále hledajici, stále výbušný ve suých inspiracích, neúnavně vpřed jdouci - nikoliv, vpřed se ženoucí." 63

(9) Janáček jako bytostný realista, tudíž anti-romantik. Za nejvýznačnější vlastnosti Janáčkovy umělecké osobnosti pokládá „sklon $k$ realismu a bezprostřednosti vnitřního života“ ${ }^{64}$ Tento sklon prý lze nápadně vidět už v Šárce, realisticky pojaté opeře zpracovávající navýsost romantickou látku. ${ }^{65}$

\begin{abstract}
„Celý potomni názor Janáčiơ na umèleckou tvorbu, jeho zbystřený zájem o skutečnou prrítomnost, at' se jevi v jeho theorii nápěvkové, nebo v jeho pozorováni př́rody, jeho prudký, až $k$ nespravedlivosti stupňovaný a vyostrený odpor proti tradicionalismu a historismu, jsou rysy výlučně realistické, které ukazuji v Janáckovi zcela odchylný typ skladatelský proti generaci Smetanově, Dvorákově, Fibichově a Foersterově." 66
\end{abstract}

Helfert nyní ještě potlačuje folkloristické aspekty Janáčkovy tvorby, ${ }^{67}$ později bude doceňovat vliv Janáčkova studia lidové hudby na jeho specifický styl, ale i v tomto př́stupu k folklóru bude pak zdůrazňovat jeho zásadní novou kvalitu: realističnost. Helfert obecně klade Janáčka jakožto bytostného realistu hlavně do protivy s romantismem, zejm. wagnerovským. Janáčkův realismus však zároveň pojímá jako domyšlení, ano dovršení romantismu:

„Janáček s jedinečnou di̊slednosti a př́močarostí domyslil a uskutečnil romantický požadavek, že hudba má být výrazem okamžitého stavu skladatelova. Všichni romantičti mistři věrili v tuto pravdu; ale žádný z nich ji nedovedl provésti do všech důsledků, nebot tradice klasicismu byla př́liš silná. Klasicistický kult formy byl jimi usmiřován s požadavkem výraznosti. Janáček ale jde v této věci vlastni cestou. Jemu požadavek výrazu, vyvřelého z rozpáleného nitra tvưrčiho, požadavek prudké a okamžité inspirace stává se proním a posledním zákonem tviorčím." 68

Zatímco Helfert koncipuje Janáčkův romantismus jako realistický, Helfertovo koncipování Janáčkova realismu je v zásadě romantické (podobně jako bylo romantické široce

63 Ibid., s. 56.

64 HELFERT, Janáčkovy neznámé opery, op. cit., s. 28.

65 Ibid., s. 38.

66 Ibid., s. 39.

67 U Nováka je v té samé době naopak vyzvedává. Viz BÁRTOVÁ, Postoje Vladimíra Helferta..., op. cit., s. 165. Zmíněné potlačování folklorismu nápadně dokládá následující citát: „K nejulastnějšímu, individuálnimu stylu sborovému dospěl Janáček nikoliv na textech lidových ani v žádném kontaktu s lidovou písni, nýbrž na umělých textech, především Bezručových, které zhudebnil svou dramatisujici methodou, jež s lidovou pisni nemá nic společného. Podobně $i$ v opeře. Po Pastorkyni obraci se Janáček k látkám nelidovým ( $t$. $j$. nikoliv ze života lidového) a dosud na této linii setrval. Jeho zájem folkloristický omezil se jen na činnost sběratelskou po případě upravovatelskou, ale do vlastni jeho tvorby nezasáhl. A tento obrat od episody [sic!] lidového realismu znamená [...] Osud“. HELFERT, Janáckovy neznámé opery, op. cit., s. 43.

68 HELFERT, Umělecké osobnost..., op. cit., s. 56. 
rozšířené pojetí realismu Balzakova): konstruuje obraz Janáčkova realismu coby umělecké tvorby podmíněné autentickým zřením skutečnosti. Tak např. o Osudu Helfert píše:

"Jeho hudebni zachyceni lázeňského ruchu i života v hudebni škole je velmi živé a opravdové a je zřejmě čerpáno z vlastnich zážitků skladatelových. Zde právě našel Janáček látku, v niž realistická tendence jeho osobnosti mohla se opříti o skutečně životni zkušenosti aspoň pokud se týče onoho vnějšího rámce vlastního děje. Je známo, čím pro Janáčka vždy byly Luhačovice a hudebni škola. V Luhačovicích také Janáček zvěděl vypravováni o skutečném př́běhu, jejž pak v Osudu zhudebnil. "69

Vidíme zde opět patrný vliv duchovědy, jmenovitě Diltheyovy koncepce „Erlebniss“.70 Dilthey píše o Goethovi coby prvém romantikovi, že základní a nejdůležitějš́ vlastností jeho poesie je, že „aus einer außerordentlichen Energie des Erlebens erwächst“. ${ }^{71}$ Takové je i Helfertovo chápání Janáčkova realismu: nikoliv jako popisného naturalismu, ale jako realismu prožitkového: výrazu subjektivizované objektivity.

(10) Zdůrazňování Janáčkových hudebních rusismů, potažmo obecné slovanskosti. Janáček je podle Helferta „zcela individuálni typ v české hudbě, jenž nemá předchůdce. Vývojové kořeny jeho uměni sahaji spiše na východ, do kulturního prostředi ruského. Zvláště Musorgský silně působil na Janácka; setkaly se zde dvě povahy značně sobě blizké." 72 Co se obecné slovanskosti týče, jedná se najmě o Janáčkův typicky slovanský soucit: „...hudba Janáčkova rozezpivá se v největši vřelost a nejsilnějši tóny tam, kde vyjadřuje soucit s trpící lidskou duší. Tento soucit stává se pak základni hybnou silou v dalšich tragických operách Janáčových a vyplňuje do velké míry smysl Janáckova tragismu. Možno v tom spatřovat rasový rys slovanský, který v literatuř nejmocněji se projevil u Dostojevského, v hudbě u Smetany. " 73

Můžeme tuto podkapitolu uzavřít konstatováním, že podobně jako v Nejedlého koncepci Velkého české skladatele ${ }^{74}$ jsou jednotlivé charakteristiky a aspekty Helfertovy koncepce Janáčka vzájemně provázené a že jedna často „vysvětluje“ či podmiňuje druhou.

\section{6-1928: od zformování janáčkovské koncepce do Janáčkovy smrti}

Další náš výklad bude o něco stručnější; zmíníme všechny texty, kterými Helfert komentoval Janáčka, a zastavíme se u některých jejich novostí.

69 HELFERT, Janáčkovy neznámé opery, op. cit., s. 44.

70 „Poesie [a umění obecně] ist Darstellung und Ausdruck des Lebens. Sie drückt das Erlebnis aus, und sie stellt die äußere Wirklichkeit des Lebens dar.” Neboli: „Im Leben sind die Kräfte enthalten, welche nun in der Phantasie wirken.“ DILTHEY, op. cit., s. 177-179.

71 Ibid., s. 179.

72 HELFERT, Umělecké osobnost..., op. cit. s. 57.

73 Ibid., s. 58.

74 ZAPLETAL, Miloš. Mezi géniem a světcem: Dekonstrukce Nejedlého koncepce velkého českého skladatele. Musicologica Brunensia, 2015, roč. 50, č. 2, s. 69-89. 
Všechna nová Janáčkova díla po roce 1925, jejichž premiéru reflektoval, hodnotil Helfert s drobnými výhradami veskrze kladně, jako díla nová a geniální. V roce 1926 informoval Helfert na stránkách Hudebních rozhledů, že vychází Janáčkova raná Suita pro smyčcový orchestr. I v tomto díle mládí už jsou podle něj rozpoznatelné charakteristické črty Janáčkova slohu. ${ }^{75} \mathrm{~V}$ roce 1926 Helfert referoval o premiéře Věci Makropulos. Novou operu nepřijal zcela bez výhrad, nebơ „prevaha hudebního dynamismu ochudila dílo čistě hudebne ““. Všechny předchozí Janáčkovy opery totiž byly v zásadě lyrické, nikoliv dramatické:

\begin{abstract}
„Utrpeni lidské duše a jeji konečné očistěni a povzneseni - to dávalo diliom Janáckovým onoho typicky janáckovského charakteru, tím také zanechávaly vždy tak hluboký dojem. A dodejme hned: tím také byly tak hudebně bohaté, nebot právě pro tyto stránky dovedl nalézti Janáček vždy tóny plné výrazové sily, něhy i náruživosti, vždy strhujici na své prosté, ale účinné výraznosti. Tyto tóny tvořily dosud, primum movens “ jeho oper. Vedle těchto tónů našel si Janáček pro scény prostého vnějšîho děje své krátké, srázné a bleskotajici motivky, které znamenaly hudebni vyjádřeni toho, čemu se ř́ká v běžném slova smyslu ,dramatické tedy pro vlastni dèj. “
\end{abstract}

I přesto je však podle Helferta nové dílo strhující, „hlavně proto, že je novým svědectvím dnes už věru těžko pochopitelné mladistvé tviorči vášnivosti a prudké dravosti. Myšlenka stíhá myšlenku, neúnavný proud řítí se nezadržitelně kupředu, není zde delši stagnace. A tak podal mistr touto Věci Makropulos nový doklad - nestárnoucí své tvưrči síly. "76 V druhé recenzi téže opery Helfert vyzdvihoval Janáčkův zcela nový a extrémní deklamační princip. Bez zajímavosti jistě není, že zde Janáčka poprvé tituloval slovem „mistr“. ${ }^{77}$

O rok později Helfert krátce recenzoval Řikadla. Považoval je za „hudebni žert, břitký vtip, vyhrocený často s neočekávanou účinnosti", obsahující však rovněž „tóny měkkého a teplého lyrismu čistě janáčkovského“. ${ }^{78} \mathrm{~V}$ tomtéž referátu zmínil Zápisnik zmizelého, patrně jej tedy v té době už prakticky znal.

Helfert, jenž jinak do oblasti hudební analýzy v užším slova smyslu př́iliš nezasáhl, napsal v roce 1927 první rozbor Sinfonietty. Konstatoval v něm, že zatímco až doposud byl Janáček ve své orchestrální tvorbě závislý na literárním programu, „znamená symfonietta nový zjev v orkestrálni tvorbě Janáckově: odklon od romantické programnosti a př́klon k,absolutni ' hudebnosti, kterou žádá moderni hudba“. Podobně jako Max Brod vidí Helfert jakousi vývojovou linii v Janáčkově tvorbě směřující k Sinfoniettě přes dřívější komorní skladby. Celkově se podle něj jedná spíše o suitu: Janáček není ze své podstaty symfonik. Popis vzniku skladby se nápadně podobá ostatním dobovým kritikám: „...mistr pưvodně chtěl napsati fanfáry pro dechovou hudbu, ale pod rukou se mu záměr změnil ve suitu“. Helfert hodnotí novou skladbu velmi vysoce: „Po výrazové stránce jsou zde všechny př́značné rysy Janáčkovy hudby - ona typická jiskřivost, vášnivý temperament, měnlivost a těkavost rytmická

75 HELFERT, V. L. Janáček: Suita pro smyčcový orchestr. Hudebni rozhledy, 1925/1926, roč. 2, č. 8, s. 131.

76 HELFERT, V. Janáčkova nová opera. Ruch, 1926, roč. 2, č. 291 (21. 12. 1926), s. 1-2.

77 HELFERT, V. Národní divadlo v Brně. Hudebni rozhledy, 1926/1927, roč. 3, č. 4/5, s. 79-80.

78 HELFERT, V. Brněnské koncerty. Hudebni rozhledy, 1926/1927, roč. 3, č. 9/10, s. 152. 
a metrická. Ale všechny tyto rysy vystupuji v tomto díle v nebývale vyrovnaném znění. Jde zde prudký temperament, ale nikoliv výbušnost. Kdyby to neznělo tak protikladně, řekl bych, že Janáček zde se bliži k jakémusi klasickému obdobi své tvorby. "79 V téže době Helfert také referoval o brněnské premiéře Sinfonietty. Napsal, že nové dílo je z Janáčkových orchestrálních skladeb „nejlepší, zvukově nejšt́astnějši a stavebně nejpevněji řešeno“, také je „dokladem podivuhodné inspiračni svěžesti mistrovy“. Pokračuje ve chvále Sinfonietty, zdůrazňuje její rusismy a považuje ji za jeden „z nejpozoruhodnějšich orchestrálnich výtvorů našich z posledni doby“. ${ }^{0}$

V samém závěru roku 1927 napsal Helfert nadšenou recenzi premiéry Glagolské mše. Zde třeba ocitovat delší pasáž:

„Janáček dokázal znova obdivuhodnou mladistvou průbojnost tvuirči, když tuto mši si vytvořil zcela po svém, po janáčkovsku. Nevázal se zde na žádnou tradici mešni formy, naopak, dílo čini dojem, jakoby postupoval vědomě proti tradici. Neni zde obvyklých forem, jež se zpravidla vyskytuji ve mších. Neni zde ani obvyklého asketismu, který je vlastni hudebnimu projevu v mešnich komposicich. [...] $V$ hudbě této mše v̌še raši ustavičným nepokojem, bleskotajici motivky mihaji se vedle čistě janáckovských vln lyrického zuroucnění, do toho zazněji sugestivni a srázné fráze vysokého tenoru nebo sopranu, vše je naplněno syrovým, prudkým životem a v̌̌s hnáno vpřed nikoliv snad předem promyšlenou formou, nýbrž nezadržitelným dynamismem urputné tvưrčí energie. Je to Janáčkova mše, jeho Sláva, jeho Věrim. Této mše nelze měriti tradičními požadavky, jež se kladou na mešni komposice. Je to vlastně kantáta na mešni text hlaholský. Tak ji Janáček také pojal, ačkoliv v úvodni a závěrečné intrádè mèl asi na mysli liturgickou přiležitost (př́chod a odchod kněží). Jako takové je to z nejsilnějších děl Janáčkových poslednich let a pripomeneme-li k tomu onu netradičnost díla, onu originalitu celkového řěseni, máme zde nový doklad podivuhodných tvưrčich sil mistrových. Hudebně dilo mnoho se kloni k Pastorkyni a $k$ Věci Makropulos. “81

Nadšená recenze Glagolské mše byla posledním textem, kterým Helfert reagoval na Janáčka během mistrova života. Zajímavé je, že kriticky nereflektoval premiéru ani jednoho ze smyčcových kvartetů, Concertina ani Capriccia; tato skutečnost souzní s tím, že Janáčka považoval především za skladatele operní, potažmo šířeji vokální hudby. Ještě krátce před Janáčkovým úmrtím vyšel v jubilejním sborníku Zemské hlavni město Brno, realizovaném k výročí deseti let samostatného Československa, Helfertův přehledový synteticko-kritický text Deset let hudby v Brně. Zde vyzdvihuje zásadní důležitost Janáčka pro rozkvět brněnské hudební kultury po roce 1918, Janáček je podle něj „vưdcem mladých, ba i nejmladšich". ${ }^{82}$

79 HELFERT, V. Symfonietta. Hudebni rozhledy 1926/27, roč. 3, č. 7, s. 111-112.

80 HELFERT, V. Koncerty v Brně. Ruch, 1927, roč. 3, č. ? (5. 4. 1927), s. ?. Uloženo v JA MZM, Janáčkovy výstř̌ižky, inv. č. 1205/41.

81 HELFERT, V. Hudba v Brně. Ruch, 1927, roč. 3, č. 280 (8. 12. 1927), s. 1-2.

82 HELFERT, V. Deset let hudby v Brně. In Zemské hlavni město Brno. Alois V. Kožíšek (ed.). Praha: E. Šolc, 1928. Helfertův text (beze změn) i celá publikace vyšly paralelně v německém překladu: HELFERT, V. Zehn Jahre Musik in Brünn. In Die Landeshauptstadt Brünn. Alois V. Kožǐšek (ed.). Přeložil F. Schleger. Prag-Karlín: E. Šolc, 1928, s. 67-72. 


\title{
1928-1939: od Janáčkovy smrti do janáčkovské monografie
}

Janáčkův odchod v létě 1928 podnítil eskalaci jeho kultu, jenž nyní zasáhl celou republiku. V množství nekrologů a dalších článků pojednávajících Janáčkův umělecký odkaz i zabývajících se jeho osobností se Helfertův nekrolog v ledasčem vyjímá, v mnoha ohledech je však textem typickým, například v utvrzování mýtu „zázračného mladého starce“. Helfert v tomto článku rekapituloval Janáčkův odkaz a významu, do jisté míry snad i proměny svého vztahu k Janáčkovi a jeho hudbě. V zásadě ovšem - a to je pro účely této studie podstatné - nevybočuje z rámce své janáčkovské koncepce, kterou jsme popsali výše. Nyní však ještě více zdůrazňuje hrdinský patos mistrova života, a v této tendenci bude pokračovat i nadále:

\begin{abstract}
„Probil se milovně a s obdivuhodnou houževnatostí, která pripominá tuhou nepoddajnost lidovou, $k$ svému vlastnimu výrazu a své vlastni tvi̊rči metodě. Jeho umělecká povaha byla v jádře strohá, prudká, živelně strhujici, vzdorná. Nezískávala teplou laskavostí. Bylo nutno na ni zvykati, snažiti se ji porozuměti. Ale jakmile jste pochopili toto tviorč́ nitro, naplněné stálým neklidem, vzpourou, štvané tviorrč vášni, která se vybijela ve vystrelujicich inspiracich, pak jste museli mít úctu k této umělecké osobnosti $i$ tehdy, když vaši povaze nebyla nejbližši. [...] Janáček stál pevně na své poznané pravdě, nepolevil a osvědčil duševni heroism, že od svého zprisobu hudebniho projevu nepopustil ani tehdy, když jím ještě nemohl dosáhnouti porozuměni nebo popularity. "83
\end{abstract}

Helfert též utvrzuje výše zmíněnou organičnost Janáčkova vývoje i jeho pozice ve vývoji české moderní hudby a historickou nutnost jeho nástupu coby nástupu hudebního realismu. ${ }^{84}$

Na janáčkovský nekrolog Helfert záhy navázal studií Janáček - čtenářr. Zjistit, co Janáček četl, bylo pro Helferta důležité, nebot’ už dříve zdůrazňoval, že v Janáčkovi „byl vždycky dvoji člověk: tvuirce a theoretik. Málokdy se oba doplňovali; většinou jeden nevěděl o druhém a co řikal jeden, to druhý popiral. " ${ }^{85}$ Pro nás je zvlášt zajímavé, že zde Helfert rozvíjí svou představu identity charakteru tvůrce a jeho díla, samozřejmě ve výše naznačeném chápání tohoto janáčkovského charakteru; tedy: jaký Janáček byl, takovou psal hudbu i literaturu, a tak také - četl. Helfert zde zdo̊razňuje - jako by chtěl zásadně protestovat proti často zmiňovanému Janáčkovu primitivismu - jeho mimořádnou vzdělanost, zejm. v oblasti estetiky. Staví jej do kontrapozice se systematikem a formalistou Riemannem, podobně jako jej jinde s oblibou staví do kontrapozice s ostatními českými skladateli. I navzdory zmíněné vzdělanosti je mu však Janáček stále především „naturálním temperamentem“. Článek končí patetickým provoláním: „Nezapřel se ani v tom: vždy a ve všem a za každou cenu svưj! A vždy v hrdé víre v sebe!" 86

83 HELFERT, V. Leoš Janáček. Ruch, 1928, roč. 4, č. 189 (19. 8. 1928), s. 2.

84 Respektive „realismu lidově zabarveného“. Ibid., s. 3.

85 HELFERT, V. Janáček - čtenár. Hudebni rozhledy, 1928, roč. 4, leták č. 4-8 (24. 11. 1928). Cit. dle Helfert,

O Janáckovi..., op. cit., s. 69.

86 Ibid. s. 75 . 
V roce 1929 řadí Helfert Janáčka po bok Beethovena, Smetany a Musorgského, když píše o „démonismu“, který tyto skladatele „posedl“. ${ }^{87}$ Tato démoničnost se bude v jeho janáčkovských textech vyskytovat i nadále: Helfert bude opakovaně psát o Janáčkově povahové jedinečnosti coby démoničnosti. Tak i Dilthey psal, že velcí básníci se od obyčejných lidí výrazně liší, jsouce „dämonische Naturen“, a proto je třeba je chápat na základě této jejich specifické duševní organizace, a nikoliv podle měřítek normálního člověka. ${ }^{88}$

Třicátá léta pro Helferta znamenají dobu soustavnějšího, vědečtějšího promýšlení Janáčkova, v té době již uzavřeného, uměleckého odkazu. V dubnu 1930 obsáhle referoval o posmrtné premiéře Janáčkovy poslední opery, Z Mrtvého domu. Sám se tomu podivuje, ale nemůže než hodnotit toto dílo jako jeden z vrcholů mistrovy tvorby. Ve všech předchozích operách, s výjimkou „klasicke“"Jeji pastorkyně, byl Janáček svazován cizím textem; nová opera, vytvořená na Janáčkův vlastní text však mu umožnila vytvořit operní dílo zcela nového charakteru, operu v pravdě janáčkovskou, naplno vyjadřující to nejdůležitější: „typicky slovanský soucit s trpicím člověkem, ten soucit, jehož nejdokonalejším mluvčím se stal Dostojevský a jenž u Janáčka dovede vždy rozezvučet nejkrásnějši a nejuroucnějši mista. "Janáček tu konečně mohl vytvořit operu vyrůstající

„...z hudby, z hudebni individuálnosti Janáckovy, v niž vždy se kmitá věčný neklid, vystř́daný jen chvilkovým lyrickým povzdechem, Janáček potreboval pro tuto svou hudebni povahu obdobného námètu, který by hověl té jeho geniální, věčně rozčilené nesoustavnosti. To pak znamenalo: text, který by pevně, logicky rozvíjel dějové pásmo, pro tento př́pad nepotřboval. Tekst v tomto díle má zcela jinou úlohu, nežli bývá obvykle. Neni zde dějovou oporou, nýbrž pouze dějovým náznakem. Ta aforistická náznakovost textu je tak nadmíru typická pro toto dílo Janáckovo a stává se srozumitelnou jedině v souvislosti s celým dílem, v souvislosti s hudbou a ovšem i jevištni akci. Tak znamená tato posledni opera Janáckova nový typ nejen v řadě jeho oper, nýbrž $i$ v celé dnešni operni situaci, typ individuálně pojatý, snad nenapodobitelný, ale tím významnější."

Závěrem obsáhlého referátu Helfert vyzdvihuje velikost poslední opery v kontextu Janáčkovy tvorby:

„Kdo s obavami pozoroval, že v Janáčkově tvorbě asi tak od Věci Makropulos se uplatňuje stále vice vnějšckvý výrazový naturalismus, který sice vedl často $k$ novým, velmi vtipným a geniálním nápadưm, ale pưsobil jakýsi suchý, přiliš racionalisticky vyvozený hudebni výraz, ten byl prekvapen hudebním bohatstvím posledni opery. V té věci toto dílo stoji na podobné základně jako druhý kvartet a vraci se $k$ hudebnim hloubkám Pastorkyně. [...] Janáčék ukazuje se zde v novém vypjeti svých tvưrčích sil - něco, co při věku, v němž dilo psal [...], je již samo sebou podivuhodné. Po stránce hudebni bych toto dílo řadil k nejlepším díliom Janáčkovým, k Pastorkyni, Káti Kahenové a Zápisniku zmizelého. "89

87 HELFERT, V. Nečasový mistr. Divadelní list Národního divadla v Brně, 1929, roč. 5, č. 9, s. 97-98. Cit. dle Helfert, $O$ české hudbě, op. cit., s. 112.

88 DILTHEY, op. cit., s. 188.

89 HELFERT, V. Janáčkův Mrtvý dům. Ruch, 1930, roč. 6, č. 98 (15. 4. 1930), s. 2. 
V témže roce 1930 Helfert publikoval článek k jubileu Vítězslava Nováka. Zde opět kladl Janáčka do protikladu k dvěma z největších žijících českých skladatelů, Foersterovi a Novákovi (nutno dodat, že toto srovnání vyznělo ve prospěch jubilanta).$^{90} \mathrm{O}$ rok později souhrnně recenzoval čtyři janáčkovské monografie; každé přiznal určitou váhu, ale žádnou z nich nepovažoval za dostatečně vědeckou. Také zde předeslal: „Umělecký zjev Leoše Janáčk a jeho osobnost budou patřit vždy k nejobtižnějším problémům hudebni historiografie, která se bude zabývat novějši českou hudbou. Obtižnost ta je dána jednak osobnosti Janáčkovou, jednak povahou jeho uměni. “91 V roce 1931 v popularizačním článku o soudobé brněnské hudbě nazývá Janáčka „východiskem, z něhož většina brněnských skladateli̊ vyrostla“;92 pojímá jej tedy podobně jako v článku Deset let hudby v Brně z roku 1928. V roce 1932 Helfert v článku Slovanská katharse tvrdil, že existuje obecný základní rys „slovanských oper“, jenž spojuje jejich tragické hrdiny. Tento jejich specificky slovanský charakter spočívá v tom,

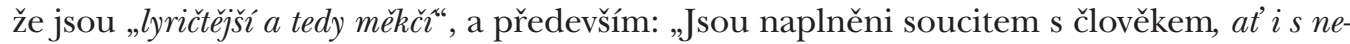
př́telem. "V tomto ohledu uvádí Janáčka jako typického představitele slovanské operní tvorby: „Vzpomeňte, jakými tóny provázi Janáček Kostelničku, když jde vraždit nemluvně! Tento hrozný zločin je zde obestřen tóny soucitu s rozvrácenou lidskou duší. Tak dovede tvořit pouze slovanský umělec!" 93

V roce 1933 vyšla v nové avantgardní hudební revui Klič další Helfertova velká studie celistvě pojednávající Janáčkův tvůrčí zjev. Zde se poprvé objevila metafora „pout tradice“, jež později dala název první části nedokončené janáčkovské monografie. Co je však důležitější, pro Helferta je tento slovní obrat metaforou konceptuální, z níž se odvíjí celé jeho chápání Janáčka: je tím hlavním, co Janáčka odlišuje od Smetany, jenž naopak na tradici stavěl a tradici rozvíjel. Tak i v této studii Helfert buduje výklad na líčení, jak Janáček poznával tradici, učil se u Dvořáka a Křížkovského, ale neustále byl svým „revolučním“ géniem puzen k vášnivosti a bouření se proti tradici. Přetrvávající vliv mentality 19. století - tainismu, a positivismu vůbec, i fascinace psychologií, fysiognomií a frenologii ${ }^{94}$ nacházíme v obšírném líčení Janáčkovy fysiognomie a jeho rodových a půdních kořenů: na vylíčení Janáčkovy bouřlivé, vzrušené hudební mluvy Helfert přímo navazuje slovy:

90 Janáček je mu typem „strohého realisty“; klade jej konfrontačně vedle „jemného snilka“ Foerstera a Nováka, jenž je „typem moderního člověka, rodicího se 20. století, t. j. doby, kdy zrak umělců se odvrací od romantických ideálio k subjektioním touhám a smutkům a k př́rode““. HELFERT, V. Vítězslav Novák. Národni politika, 1930, roč. 48, č. 334 (5. 12. 1930). Cit. dle Helfert, O české hudbě, op. cit., s. 116. Podle Bártové si Helfert kromě Smetany cenil ze všech českých skladatelů nejvíce právě Nováka. BÁRTOVÁ, Postoje..., op. cit., s. 165.

91 HELFERT, V. Brod Max, Leoš Janáček, Život a dílo. Veselý Adolf, Leoš Janáček, Pohled do života i díla. Vašek Adolf E., Po stopách dra Leoše Janáčka. Kapitoly a dokumenty k jeho životu a dílu. Muller Daniel, Leoš Janáček. Časopis Matice moravské, 1931, roč. 55, s. 538. Samostatně pak ještě na stránkách Indexu referoval o Vaškově a Mullerově knize: HELFERT, V. Nové knihy. Index, 1931, roč. 3, č. 1, s. 12; č. 2, s. 24. V druhé části recenze pojednává též o Moravských pisnich milostných.

92 HELFERT, V. Brněnští hudební skladatelé. Vzdělání a štěstí, 1931, roč. 2, č. 2, s. 5-8. Cit. dle Helfert, O české hudbě, op. cit., s. 132.

93 HELFERT, V. Slovanská katharse. Divadelni list Zemského divadla v Brně, 1932-1933, roč. 8, č. 9 (7. 12. 1932), s. 231. Srov. ZVARA, Vladimír. Leoš Janáček and the „Slavic catharsis“. International Review of the Aesthetics and Sociology of Music, 2012, roč. 43, č. 1, s. 23-34.

94 Jež ovšem pronikla i do diskurzu duchovědného, tak např. Dilthey napsal: „...unsere[r] physiologischen Bedingtheit auch in den höchsten Offenbarungen des Gemütslebens durchdrungen sind“. DILTHEY, op. cit., s. 191. 
„Takový byl i ve svém celém zjevu. Jeho krásná hlava ověnčená bílou hř́vou - to nebyla klasická krása někoho, kdo svým dlouhým životem si vykoupi vyrovnaný klid stář́i." 95 O krásných hlavách bude Helfert psát i v dalších svých povahozpytných textech (o Zdence Janáčkové, Smetanovi ad.), zde však pokračuje takto:

„V jeho tváríi, v očích, v každé žilce kolem oči a kolem úst při hovoru cosi stále neklidně hrálo a turdé rysy energické brady s ohněm oči dosvědčovaly, jaký nezdolný vzdor drásá stále nitro tohoto nestárnoucího starce. A jeho mluva, ona př́značná úsečná mluva lašská, jižz zưstal věren po celý svưj život, jeho prudké slowni výpady, kdykoliv narazil na neporozuměni nebo dokonce na odpor [...] - to vše bylo věrným předobrazem jeho hudebni fysiognomie. Janáček byl svým především jako člověk, byl ojedinèlým zjevem $v$ přirodopise našich hudebnich tviorců - jeho hudebni mluva byla důsledkem tohoto svérázného typu. "96

Janáčkova tvrdá, mužná povaha se slučovala s jeho lyrismem: lyrismem člověka prudce (ale zdravě, nikoliv dekadentně!) erotického a plného soucitu s trpícími, člověka bytostně slovanského. Janáček byl nezdolně vitálním. Celý jeho život byl heroickým zápasem za jeho, zcela novou pravdu. Helfert v tomto textu už neupozad’uje Janáčkův folklorismus, naopak uvádí lidovou hudbu jako jeden z hlavních vzorů mistrova svérázného stylu: „Janáček nenaslouchal lidové hudbě jako externi zájemce nebo pozorovatel; hudbu tu do kořene prožíval a v ni zároveň veškerý lidový život, cítě se sám jednotkou toho lidu. " 97 Kromě jiných obšírných líčení, kterými se zde nebudeme zabývat, nebot převážně odpovídají výše načrtnuté Helfertově koncepci, pojednáme ty momenty, kdy Helfert opět buduje obraz Janáčkovy jedinečnosti na základě srovnávání se Smetanou. Smetana je mu „architektonikem“, tvưrcem klasickoromantické syntézy. A Janáček?

„Janáčkovi nejde o architekturu, nemá smyslu pro tento výkvět lidské kultury a lidské civilisace. Miluje prostou přírodu, nahý život. Byl dítětem valašských lesů a hor a jím též zůstal. Nebyl romantickým snilkem, jenž by $v$ zášeři lesa anebo i salonu roztouženě dumal o krásách přirody. Byl mužem skutečného života, nezastřeného, nestylizovaného, miloval život takový, jaký je, se vši krásou, ale i se vši hrůzou a krutostí. A takovou také miloval přirodu. Janáček byl mužem pravdivé reality. A tedy přeneseno na jeho styl: hudebni myšlenka mu nebyla materiálem, z něhož by měl teprve vytvárét stavbu; byla mu již hotovou hudební realitou, skutečností, která mu znamenala již kus dila. Nevyvozoval z ni hudebni organism, nýbrž vyvozoval tento organism jí. To jej vedlo $k$ opakováni motivů, $k$ oné technice, kdy určitý motiv byl mluvč́m určité situace a zazníval, často opakován beze změny tak dlouho, dokud trvala situace. [...] Janáček tak představuje u nás skladatelský typ realistický. Je proním a dosud v té důslednosti jediným, jemuž možno dát tento název. “98

95 HELFERT, V. Janáčkův tvůrčí typ. Kličc, 1932-1933, roč. 3, 17-18, s. 244-249. Cit. dle Helfert, O Janáčkovi, op. cit., s. 64 .

96 Ibid., s. 64-65.

97 Ibid., s. 67.

98 Ibid., s. 66. 
Závěrem však Helfert konstatuje, že „genialita inspirace je jen částí vrcholné geniality. K té je třeba ještě geniality tvưrči práce, která z geniálni myšlenky vytvoři geniálni celek. Této druhé geniality Janáček nedorostl. Jeho dynamicky formotvorný princip nestačil, aby nahradil ty tradični strukturálni principy, proti nimž se postavil." 99 Tento nedostatek lze prý nejlépe pozorovat vJanáčkových skladbách instrumentálních.

V právě pojednané studii Janáckưv tvưrči typ se Helfert těsně přiblížil nejedlovské koncepci Velkého českého skladatele. Jednak tím, že základním východiskem pro pochopení díla a jeho charakteru se mu stává povaha autora (a ta je zase odvozena od autorova rodu a původu), jednak líčením skladatele coby jakéhosi novodobého světce, ideálního člověka a mravního vzoru. ${ }^{100}$ Obecně můžeme konstatovat, že s přibývajícími roky Helfert Janáčka víc a více doceňoval v neprospěch jeho generačních souputníků: „Kde pak zưstal Fibich a jeho generace?" táže se řečnicky. „Ti všichni utkvěli v romantismu, z něho se nedostali a v něm namnoze $i$ utonuli. Vedle nich jde si úporně tento vzdorný šohaj svou cestou, za vlastním výrazem a vlastnim stylem."101

Zmíněný obraz Janáčka Helfert v témže roce rozvíjel a konkretizoval ve studii o vzniku Jeji pastorkyně. Ta je podle něj operou ve své době zcela novou, dílem heroického zápasu, a především „dilem bolesti“. Patos utrpení a zápasu se stává v líčení vzniku Pastorkyně klíčovou instancí: jak kvalitativně, tak kvantitativně. Jeji pastorkyně je Janáčkovým dílem největším, protože vykoupeným největším utrpením: umíráním a smrtí dítěte. Zřetelně se zde ozývá beethovenovský mýtus: velké dílo je vykoupeno utrpením, a tuto daň platí skladatel svému úhlavnímu protivníkovi, jímž je personifikovaný Osud. Zde mohla svou sehrát roli Rollandova kniha La vie de Beethoven (1903), jež vyšla v českém překladu poprvé v roce 1919 a byla u nás (už i dříve) poměrně hojně čtena. ${ }^{102}$ Tímto Helfertovým výkladem získává Pastorkyně svou auratickou sílu a pravdivost: „Chápete nyní, že tóny Jenưfina děsivého strachu o život vlastního děcka a jejího žalu nad jeho smrtí vyvřrly z mučivých úzkosti Janáčkovy duše? Že to jsou stránky psané krvi jeho srdce?" 103 Podle o rok mladší verze studie bylo Janáčkovo utrpení přímo zdrojem této opery. ${ }^{104}$ Tuto představu autentičnosti (coby před-prožitosti) umělcových postav nacházíme opět u Diltheye, ${ }^{105}$ ale také u F. X. Šaldy, jenž požadoval, aby umění vycházelo ze životního prožitku a tím získávalo svou vnitřní pravdivost; Šalda též klade umělcův charakter jako základní faktor určující charakter (i formu!) jeho díla,

99 Ibid., s. 67.

100 ZAPLETAL, Mezi géniem a světcem, op. cit., s. 69-89; ke zmíněnému determinismu viz ZAPLETAL, From Tragedy to Romance, op. cit., s. 99-124.

101 HELFERT, Janáčkiv tvưrči typ, op. cit., s. 65.

102 ROLLAND, Romain. Život Beethovenův. Praha: B. Kočí, 1919. Srov. HRABAL, op. cit., s. 15.

103 HELFERT, V. Něco o vzniku „Její pastorkyně“. Divadelni list Zemského divadla v Brně, 1933, roč. 9, č. ? (29. 9. 1933), s. 65-72. Cit. dle Helfert, O Janáčkovi, op. cit., s. 49.

104 HELFERT, V. Bolestný zdroj Janáčkovy Pastorkyně. Magazin Družstevni práce, 1934/1935, roč. 2, č. 5, s. $146-149$.

105 Dilthey píše: „Das Verhältnis der Phantasie zu ihren Gestalten gleicht innerhalb gewisser Grenzen dem zu wirklichen Menschen. So lebte Dickens mit seinen Gestalten als mit seinesgleichen, litt mit ihnen, wenn sie der Katastrophe sich näherten, fürchtete sich vor dem Augenblick ihres Untergangs. Balzac sprach von den Personen seiner comédie humaine als ob sie lebten“. DILTHEY, op. cit., s. 187. 
a ve velmi podobném duchu líčí Nerudu: jako zneuznaného génia, jenž přetavuje autentický prožitek svého utrpení do své tvorby, která tak získává svou vnitřní pravdivost. ${ }^{106}$

Jeji pastorkyni se v té době Helfert zabýval všemožně: odborně, editorsky. V předmluvě k edici klavírního výtahu opery v roku 1934 napsal: „Dnes ovšem víme, že tehdy nezvyklé drsnosti Janáčkova orchestru patřily ke zvláštnostem jeho stylu a dnes, poučeni rozvojem moderní hudby, nepohlíżime na ně jako na nedostatek, nýbrž jako na znak individuálnosti mistrovy. " 107

V téže době Helfert vybízel k soustředění památek po Janáčkovi, přičemž zdůrazňoval jeho zásadní roli v kulturní renesanci Brna, jakož i jeho vlastenecké snahy (dokládá je klavírní sonátou). ${ }^{108}$

Již několikrát jsme zmínili, že Helfert s oblibou a rétoricky účinně buduje svůj výklad na kontraposicích Janáčka a jiných významných českých skladatelů, nejednou k takovému srovnávání využívá dokonce skladatele ze svého pohledu největšího, absolutního - Smetanu. Koncepce Smetana vs. Janáček našla své konkrétní vyjádření v článku nazvaném př́íznačně Zwei Gegenpole der Tschechischen Musik, jenž vyšel v roce 1934 v časopisu Anbruch. Přestože Dykast tvrdí, že proměna Helfertova muzikologického myšlení po přesunu do Brna znamenala zejména „odpor $k$ psychologismu“, ${ }^{109}$ Helfertův výklad v mnoha janáčkovských textech, tento nevyjímaje, je budován psychologistně: Smetana a Janáček jsou pro Helferta především „dva psychicky protichůdně organisované zjevy“; ${ }^{110}$ a od této distinkce se odvíjejí všechny ostatní (přičemž je opět kladen velký důraz na fysiognomii a vliv prostředí). Smetana je především klasikem: „již jeho zjev prozrazuje okamžitě protiromantického umělce. Máme před sebou hlavu, která dovede jasným pohledem ovládnout tvưrči inspirace." To Janáček je po všech stránkách zjevem zcela protichůdným: „Proti architektoniku Smetanovi vystupuje zde samorostlý přirodní zjev, bez porozuměni pro klasickou krásu. "Co však oba skladatele zásadně spojuje? „[Janáček] zůistane provždy přikladem věčně mladého umělce. Nebot' ukázal, jako u nás kromě Smetany sotva někdo druhý, že cesta Tvưrcova je nepretržitá snaha upřed, neustálé dobýváni. "Zajímavá a nová (nebo alespoň poprvé takto formulovaná) je též myšlenka, že Janáčkův úspěch po roce 1918 souvisel s nástupem vkusu „nové věcnosti“, coby konečnou porážkou „romantismu“.111

V knížce Pohled na Bedřicha Smetanu řadí Helfert Janáčka spolu se Smetanou mezi představitele „slovanské“ opery - zcela v duchu o něco staršího článku o „slovanské katharsi“. ${ }^{112}$

106 ŠALDA, František Xaver. Neruda poněkud nekonvenční. In F. X. Šalda. Duše a dílo: podobizny a medailony. Praha: Melantrich, 1937, s. 106 nn. Šaldův zásadní kritický spis Duše a dílo vyšel prvně roku 1913.

107 HELFERT, V. Předmluva ke třetímu vydání. In Leoš Janáček. Jeji pastorkyña. Klavírni výtah se zpěvy. Praha: Hudební matice Umělecké besedy, 1934, s. 7-8. Předmluva vyšla též samostatně jako: HELFERT, V. Z předmluvy ke třetímu vydání Její Pastorkyně. Tempo, 1934/1935, roč. 14, č. 4, obálka (její 4. str.).

108 HELFERT, V. Soustředění památek po Leoši Janáčkovi. Tempo, 1933-1934, roč. 13, s. 105-108. Cit. dle Helfert, O Janáčkovi, op. cit., s. 88.

109 DYKAST, Roman. Metodologická východiska Helfertovy koncepce ve srovnání s jinými dobovými estetickými koncepty. In Helfertova Česká moderní hudba, op. cit., s. 15-20. Srov. POLEDŇÁK, Ivan. K některým otázkám, op. cit., s. 502.

110 HELFERT, V. Zwei Gegenpole der Tschechischen Musik: Smetana und Janáček. Anbruch, 1934, roč. 16, s. 63-65. Překlad cit. dle Helfert, O Janáčkovi, op. cit., s. 60.

111 Ibid., s. 63.

112 HELFERT, V. Pohled na Bedřicha Smetanu. Brno: Index, 1934, s. 9. 
Dostáváme se do poloviny třicátých let. V té době Helfert „viceméně zanechává své pravidelné kritické činnosti“ ${ }^{113}$ a též ve svém psaní o Janáčkovi se od nynějška soustředí spíše na úžeji muzikologické promýšlení jednotlivých janáčkovských problematik.

V roce 1936 Helfert dovršil zařazení Janáčka mezi klasiky české hudby v článku pro britský časopis The Slavonic Review. Zde překvapivě vřadil Janáčka do „generace, která položila základy české hudebni tradice“, tedy po bok Smetany, Dvořáka a Fibicha, zatímco Suka, Nováka a Ostrčila pojal jako průkopníky „českého modernismu v hudbě“. ${ }^{114}$ Tímto netušeným historicko-koncepčním postupem se dostáváme k Helfertovu vrcholnému syntetickému dílu, České moderni hudbě, ${ }^{115} \mathrm{v}$ němž podal svou filosofii dějin moderní české hudby. ${ }^{116}$ Obdobně předchozímu textu i zde je Janáček vřazen do kapitoly pojednávající „prvni generačni vrstvu“ a „zakladatele“ české moderní hudby (Smetana, Dvořák, Fibich). Pohled’me nyní na celou janáčkovskou část České moderni hudby z hlediska argumentačního schématu. To odpovídá v zásadě dřivější, výše popsané Helfertově koncepci: moravské prostředí Janáčkova původu určilo jeho specificky moravskou povahu, vyznačující se sklonem k realismu. ${ }^{117}$ Tento obecný sklon k realismu se v umělci projevil tíhnutím k uměleckému realismu, a tudíž odporem k uměleckému romantismu. ${ }^{118}$ Právě moravský původ, podmiňující specificky moravskou psychiku („psychologickou organisaci“), je tím zásadní aspektem určujícím novost Leoše Janáčka v dějinách moderní české hudby:

"Jsa nadán prudkým, často drsným a urputně útočným temperamentem, je hnán kupředu věcným nepokojem, stálou horkou touhou jít dál a dál bez oddechu, bez spočinutí, všem navzdory. Jsou to rysy, jež si přinesl na svět s rodnou krvi i po svém lašském pưvodu. Z toho pak vyrostla jeho komposični metoda. "119

Novost této metody spočívá především v absolutním odklonu od Smetanova a Dvořákova „architektonického“ klasicismu i od Fibichova romantismu: tedy v absolutním realismu. S Janáčkovým bytostným realismem souvisí též jeho zcela nový poměr k lidové

113 MAJER, Jiří. Vladimír Helfert jako kritik brněnské opery. In Vladimír Helfert v českém a evropském kontextu, op. cit., s. 93 .

114 HELFERT, V. Dvě ztráty české hudby: Josef Suk, Otakar Ostrčil. The Slavonic Review, 1936, sv. 14, č. 42, s. 639-646. Cit. dle Helfert, O české hudbě, op. cit., s. 124.

115 O Helfertově ČMH pojednávají stati ve sborníku Helfertova Česká moderní hudba, op. cit.

116 Srov. SYCHRA, Antonín. Vladimír Helfert a smysl české hudby. Hudební rozhledy, 1961, roč. 14, č. 5, s. 184-187.

117 „Zdá se, že půda Moravy nebyla přiznivá tomu, aby z ni vzklíčilo semeno romantismu. Povaha Moravanů, zvláště ve středni a východni části, se vyznačuje zuláštním smyslem pro konkrétni reálnost. Vládne tam zcela jiná povaha nežli $v$ Čechách, zvláště ve stredni a východni části Čech, kde se setkávám e s daleko větši náklonností $k$ romantickému vzplanuti a $k$ romantickým emocím nežli u Moravanů. Proto jistě neni náhodou, že právě z moravské půdy vyšli význačn predstavitelé literárního a politického realismu v čele s T. G. Masarykem." HELFERT, V. Česká moderní hudba. Studie o české hudební tvořivosti. In Helfert, Vybrané studie, op. cit., s. 210.

118 „Něco podobného bylo i v hudbě. V době, kdy v Čechách romantismus stále vyvolává nové podněty, v době, kdy tam rozvijji své síly typický romantik Fibich, roste na Moravě tvůrce, který jde zcela jinou cestou nežli romantickou, který si osvojil zcela jinou tvưrči metodu a představuje osobnost ve všem odchylnou od dosavadnich postav, jež dosud kolem nás prošly. Ale právě touto ostř vyhraněnou individuálností rozšiřuje podstatně obzory české hudby.

Je to Leoš Janáček “. Ibid.

119 Ibid. 
hudbě. ${ }^{120}$ Autentické poznání a prožití vokální lidové hudby a mluvené řeči zapříčinilo, že se Janáček stal „tviorcem zcela nového vokálniho stylu českého: jeho vokálni melodické fráze a deklamačni linie maji zcela novou, pronikavou a úsečnou výraznost. Proto také Janáček je skladatelem predevšim vokálním. "Revoluční zavrhnutí operní tradice (zejména wagnerovské) a přimknutí se ke vzorům ruským vedlo $\mathrm{k}$ vytvoření „nového typu operního: realistické české opery“. ${ }^{121}$ Zajímavá je v této souvislosti rovněž marginální poznámka, že Výlety páně Broučkovy prý se nesetkaly „s takovým uměleckým zdarem, jako ostatni jeho opery“. ${ }^{122}$

I přes opakovaně zdůrazňovanou Janáčkovu novost a výlučnost jej Helfert v České moderni hudbě, jako už ve své koncepci z roku 1925, vřazuje do organického, teleologicky chápaného vývoje moderní české hudby:

„Časová posloupnost této generace ukazuje podivuhodnou vývojovou logiku. Nejprve príšel Smetana se suým budovatelstvím, se svým principem pevného řádu a se svou synthesou tvuirči extase a tvưrčím řádem. Teprve na tomto základě se objevuje geniálně rozsochatý zjev Dvořákưv, jenž se stavi vedle Smetany. Oba tvuircové přinášejí do české hudby dva principy vzájemně se doplňující. A totéž platí o Janáčkovi, jenž otvírá české hudebni tvořivosti obzory novým směrem. "123

Závěrem k České moderni hudbě dodejme, že zde Helfert vůbec nezmiňuje dvě z nejavantgardnějších Janáčkových děl, Concertino (prem. 16. 2. 1926 v Brně) a Capriccio (prem. 2. 3. 1928 v Praze).

V roce 1937 vyšlo v Pazdírkově hudebním slovniku Helfertovo obsáhlé heslo o Janáčkovi, psané v duchu výše popsané koncepce a jejího stavu z poloviny třicátých let a utvrzující logiku Janáčkova uměleckého vývoje. ${ }^{124}$ Celkový výklad je na slovníkové heslo neobvykle vášnivý, patetický a osobně angažovaný, má vlastně charakter hudebně-kritického textu: romance géniova vítězství. ${ }^{125}$ Helfert zde hutně shrnuje Janáčkův význam v dějinách

120 Ibid., s. 211.

121 Ibid., s. 212.

122 Ibid., s. 213.

123 Ibid., s. 215.

124 Tak v Šarce „,uplatňuje se již čistě J-ưv výraz, jenž vychází nejvice z Dvořáka, a připravuje se jeho nový dram. sloh, jenž se odkláni od stylu Wagnerova“. Jeji pastorkyně je už „mistrovské dílo, v němž dosáhl J. svého vlastního dram. slohu, nezávislého na romantické metodě Wagnerově a rozvinul individuálni výraznost vokální melodie, jež vycházi ze studia mluveného spádu lidové réč [...]. Hluboké tragika a vrouci citovost prameni z bolesti nad smrtelnou nemocí dcery Olgy. “ Helfert též zdůrazňuje Janáčkovo „uvědomèlé rusofilstvi". HELFERT, V. Janáček, Leoš. In Pazdírki̛o hudebni slovnik naučný. II., Část osobni. Svazek proý, A-K. Gracian Černušák - Vladimír Helfert (eds.). Brno: Ol. Pazdírek, 1937, s. 472-473.

125 Do roku 1916 byl ,J-ĩv osud neobyčejně tordý, pro svioj odlišný sloh byl chápán jenom několika práteli, soustavná odmítáni v Praze cítil jako krutou potupu [...], skladatelské dílo bylo téměr neznámo. Veliké duševni sily bylo třeba, aby neklesl a udržel svou linii. “ Poslední Janáčkovy skladby dokazují „tviơrč průbojnost a neochabujicí sílu výrazu mistra více než 70letého“. „Neni snad př̌kladu, aby se sklad. po tak turdém životě dopracoval ve vysokém věku takového vitèzství jako J." Tarase Bulbu pokládá Helfert za Janáčkovu "největši symf. báseñ" a za „výraz slovanského uvèdomeni". Zápisnik zmizelého je pak "geniálni cyklus" a Potulný šilenec je "geniálni sbor". Helfert zde již pojednává Concertino a první smyč. kvartet mezi díly „nového komorního stylu“. Listy dũvěrné jsou „svědectvím melodické vroucnosti a citové intensity 74letého mistra". Ibid., s. 474. 
české moderní hudby, klada jej mezi její tři největší zjevy (triumvirát Smetana - Dvořák - Janáček). ${ }^{126}$

V knize Die Musik in der Tschechoslovakischen Republik dokončené na podzim 1937 Helfert řadí Janáčka do kapitoly „Die Begründer der Tschechischen Musik“. Převypravuje zde - v kontextu „vývoje československé [sic] hudby“ - zhuštěně vše, co v té době psal o Janáčkovi, a uzavírá celou kapitolu konstatováním, že „die ersten Meister der tschechischen Musik“ jsou: Smetana, Dvořák, Fibich a Janáček. ${ }^{127}$

Kromě toho, že v roce 1937 brojil proti Talichovým úpravám Lišky Bystroušky, ${ }^{128}$ vrátil se Helfert samostatnou studií k jednomu ze svých nejoblíbenějších Janáčkových děl, ke kantátě Amarus. ${ }^{129}$ Podobně jako ve studii o Jeji pastorkyni z roku 1933 i zde Helfert líčí vrcholné umělecké dílo jako vytrysklé ze samotného života umělce: Amarus je rovněž „dílem bolesti“. Helfert popisuje Janáčkův od dětství tvrdý a málo radostný život, dospívaje k zjištění, že „v Janáčkovi bylo kus osudu Amara“. Proto ve „slovech Vrchlického našel [...] kus svého osudu. A takév té horečné touze Amarově po štěstí. V té touze, která právě tehdy jitřila nitro mistrovo, kdy churavěla jeho radost a pýchy, dcera Olga, a kdy ho drásaly jeho démonické sily. Amarus je dílo Janáčkovy bolestné touhy po štěstí a životním jasu. " 130 Zas a znovu, v každém dalším textu Helfert utvrzuje auratický status Jeji pastorkyně a Amara, nepřestávaje zdůrazňovat jejich opravdovost a prožitost i to, že byla vykoupena největší daní, jsouce takto z jeho děl nejlepšími. Přestože nejpozději od roku 1924 Helfert proklamoval nutnost objektivního a k samotné hudební logice zacíleného studia „hudebního myšlení“ či „hudební tvořivosti“, jeho psaní o Janáčkovi zůstávalo i nadále v základu romantické či duchovědné: étos autentického géniova prožitku znamenal pro Helferta implicitně základní podmínku a př́činu velikosti a patosu Janáčkových děl. ${ }^{131}$ Tak tomu

126 „V české hudbě je J. zcela novým zjevem po Smetanovi a Dvořákovi. Klasický a romantický zpưsob skladebný, jenž dává důraz na vytřibenou stylisaci, nahrazuje realistickou výraznosti motivů, která vyvírá z prudce vznětlivé a hluboce citové osobnosti. Proto maji jeho skladby, zvl. instrumentální, často rapsodický ráz. [...] Při svém prudkém, nezkrotném temperamentu, který ho neopustil ani ve stárí, byl duch hluboce zvídavý [...]. Jeho neromatický, realistický hud. sloh, byl po prevratu prijimán jako jeden z nejpokrokovějšich projevů moderni hudby a J. se tehdy postavil v čelo české hud. tvorby. " Ibid.

127 HELFERT, V. Die Entwicklungslinie der tschechoslovakischen Musik: Eine informative Studie. In V. Helfert - Erich Steinhard. Die Musik in der Tschechoslovakischen Republik. Prag: Orbis, 1938, s. 54-61. Jedná se o upravenou verzi knihy HELFERT, V. - STEINHARD, Erich. Geschichte der Musik in der Tsechoslovakischen Republik. Prag: Orbis, 1936. Vyšla též francouzsky.

128 HELFERT, V. Závaznost dokumentu. Index, 1937, roč. 9, č. 6, s. 65-66.

129 Tak jako v př́padě Pastorkyně, i svou studii o Amarovi Helfert záhy přetavil v předmluvu k edici tohoto díla; viz HELFERT, V. Janáčkova legenda „Amarus“. In Leoš Janáček. Amarus. Praha: Hudební matice Umělecké besedy, 1938.

130 HELFERT, V. Janáčkův „Amarus“. Hudebni noviny, 1937/1938, roč. 5, č. 5, s. 20-21. Cit. dle Helfert, O Janáčkovi, op. cit., s. 52.

131 Zpočátku definoval „hudebni myšleni“ ryze formalisticky (HELFERT, Čeho je potřeba, op. cit., s. 1.), později kladl velký důraz též na studium inspiračních faktorů, ovšem kritérium „čistě hudební pro něj bylo klíčové. $\mathrm{V}$ této pozdější podobě nebyla tedy jeho koncepce hudebního myšlení v tak příkrém rozporu s jeho namnoze duchovědnou praxí. K vnitřnímu sváru Helfertova estetického objektivismu a intuitivismu srov. BURJANEK, Poznámky..., op. cit. 
bylo i v textu, jímž pojednal Elegii, druhou skladbu, kterou Janáček věnoval památce své nebohé dcery. ${ }^{132}$

V samostatné studii o Janáčkově manželce Zdence z roku 1938 tuto ženu traktoval jako jakýsi Janáčkův protipól, dávající vysvitnout jeho specifičnosti:

„...tato jemná a ušlechtilá bytost byla osudem pripoutána ke geniovi, v němž stále háraly temné síly tvưrčiho daimonia. Na jedné straně bytost, která vyrostla v pečlivé isolaci na půdě úzkostlivě udržované patricijské tradice - na druhé straně elementárni zjev umèlce, jenž všemi svými rodovými kořeny tkvěl $v$ syrové půdě moravského venkova, muž rostouci z lidových tradice, které niky nepriš̌ly v delši styk s městskou kulturou, umèlce, jenž si po předcích přinesl strhujici prudkost a náruživou životni energii, takovou nezadržitelnou živelnou vitalitu, která tvořila podstatnou základnu jeho tvuirči osobnosti. Povyšte si pak tyto rodové rysy do sféry tvưrči živelnosti a pochopite, že tento rostouci genius byl po celý život strhován vášnivými životními víry, do nichž se dovedl střemhlav vrhat, bez rozmyslu, puzen jen svou nezkrotnou vĩli, nalézat stále nové a nové tvưrč́ podněty. Tento umèlec, takto cele a nekompromisně se nořici do životni výhně, tento podivuhodně komplikovaný duch, který dovedl být krutě vášnivý, ale hned nato se rozeplál horoucí láskou $k$ člověku a soucitem s trpícím človèkem, tento zjev, který mèl tak neskonale blizko $k$ oněm ruským postavám Dostojevského, které toutéz̆ rukou dovedou pokořovat a ničit a hned na to horoucně objimat a modlit se, tento živelný zjev umělecký byl postaven osudem k oné jemné bytosti, o niž plným právem lze říci, že to byla anima candida." 133

Vidíme zde tedy opět výklad založený na rodové a půdní determinovanosti, a též dále se v onom textu zdůrazňuje trpitelský patos Janáčkova život a díla. Ona démonická komplikovanost a podivná dvojakost Janáčkova ducha může mít předobraz u Šaldy. ${ }^{134}$

Téhož roku Helfert ve studii o Janáčkově kritické tvorbě pokračoval v rozvíjení své koncepce: opět vysvětloval logiku a organičnost Janáčkova vývoje, dokazoval, že velký duch se svérázně projeví v každé oblasti života a tvorby (jež de facto jedno jsou), znovu porovnával Janáčka se Smetanou coby dva protipóly - kladené však dialekticky v rámci Helfertovy koncepce dějin moderní české hudby. Helfert zde opět používá metaforu „pout tradice“ a Janáčkovu od počátku přítomnou vnitřní divokost a komplikovanost ${ }^{135}$ vyjadřuje oxymóronem „přesvědčený a ohnivý vyznavač pokojného tradicionalismu“. ${ }^{136} \mathrm{~V}$ líčení

132 HELFERT, V. Janáčkova elegie nad ztrátou dcery Olgy. Hudebni noviny, 1937/1938, roč. 5, s. 18. Jedná se o přetisk úvodu ke klav. výtahu Elegie.

133 HELFERT, V. Paní Zdeňka Janáčková. Tempo, 1937-1938, roč. 17, s. 114-116. Cit. dle Helfert, O Janáčkovi, op. cit., s. 85 .

134 Šalda svůj výklad géniů (Mácha, Flaubert aj.) opakovaně buduje na základě takovéto dualistické, faustovské koncepce. Viz např. ŠALDA, František Xaver. Mladý Flaubert: Epilog romantismu. In Šalda, Duše a dílo, op. cit., s. 317. Jako „démonické“ živly, „zjevy úžasně složité, přmetné a horké, plné skrytých možnosti zmaru a roztřǐstění, povahy bolestné a bolavé, šilené, pracně krocené impulsivnosti“ líčí Šalda moderní génie též ve svém programovém textu z roku 1905, viz ŠALDA, František Xaver. Nová krása: její genese a charakter. In F. X. Šalda. Boje o zítřek. Duše a dilo. Praha: Melantrich, 1973, s. 101.

135 Pro Šaldu je - v návaznosti na V. Huga - „moderní genius“ především komplikovaným duchem. ŠALDA, František Xaver. Karel Hynek Mácha a jeho dědictví. In Šalda, Dǔ̌e a dílo, op. cit., s. 54.

136 HELFERT, V. Kořeny Janáčkova kritického stylu. In Janáčkovy feuilletony z Lidových novin. Jan Racek - Leoš Firkušný (eds.). Brno: Dobročinný komitét, 1938, s. 22-28. Cit. dle Helfert, O Janáčkovi, op. cit., s. 77. 
Janáčkova uměleckého přerodu je zase př́itomný onen naturalistický determinismus: „... přece jen v hlubinách jeho nitra doutnala jiskra, která se záhy rozhořela v požár, jenž propálil a probořil tu zdánlivě pevnou budovu klasicismu a formalismu“. Ten se kombinuje s dozvuky ryze romantické vize démonického génia: „Ten tuhý klasicismus a formalismus, jimž prošel, znamenal pro Janáčka krunýr, který si dobrovolně oblékl, aby ztužil a zocelil svou duši, v niž vždy bouřily temné démonické síly. Janáček se spoutával často s nadlidským úsilím a s heroickým odhodláním, aby se nezmocnily jeho nitra a nestrhly na sráze, v nichž by se již nedovedl ovládat." Zásadním momentem Janáčkova přerodu bylo podle Helferta setkání s autentickou a realisticky nahlíženou lidovou hudbou; ovšem i tento moment byl podmíněn (!) Janáčkovým rodovým a půdním zakotvením. ${ }^{137}$

Helfertova pout za Janáčkem vyvrcholila torzem velkolepě pojaté monografie, jejíž první díl vyšel k desetiletému výročí mistrova úmrtí v roce 1939. Koncepci svého výkladu Janáčkova života a díla Helfert nastínil ve všech svých předchozích janáčkovských textech napsaných po roce 1924; příznačně ji vyjadřuje také Helfertův rozvrh janáčkovské biografie: 1) „V poutech tradice“, 2) „Vzpoura“, 3) „Boj“, 4) „Vítězství“. V závěru předmluvy k prvnímu dílu monografie se Helfert vyznal ze svého komplikovaného vztahu k Janáčkovi i upřímné snahy najít k němu cestu. Dnes se tato pasáž jeví tím dojemnější, že byla skutečně posledním větším janáčkovským textem, který Helfert publikoval:

\begin{abstract}
„Jeho umèlecká cesta $k$ tvi̛rčimu realismu byla postavena na zcela jiných základech a šla jiným smèrem, nežli jakým se vyvíjela česká hudba. [...] Je proto přirozené, že tam, kde kritický poměr k české hudbě se opiral o vývojové predpoklady klasicko-romantické, dlouho se nemohlo porozumět Janáckovi a namnoze se mu dosud nerozumi. Patřil jsem k těm, kteří, vyrostše z naznačených předpokladi̊, mívali odmítavé stanovisko k Janáckovi. Když jsem však poznal od svého přichodu do Brna v r. 1919, kterak hudba na Moravě vyrostla na jiných základech nežli v Čechách [...], když jsem měl nadto možnost poznat vývojovou linii Janáckovu pred Pastorkyni, ukazujici organickou logičnost jeho vývoje k vlastnimu stylu [...], tehdy to vše mne prìvedlo di̊sledně $k$ novému kritickému poměru k Janáckovi. Poznal jsem v něm zjev sui generis, který mèl své vlastni vývojové předpoklady a svůj vlastni tvuirči rưst a který svou vývojovou a stylovou svéprávností obohatil tvưrči oblasti české po B. Smetanovi. "138
\end{abstract}

Opravdu patetický historický rozměr potom získává závěrečné provolání, psané šest dnů po Mnichovu:

„Janáček, tento mužz lidu, tento tviorce, zakořeněný hluboce svým rodem a celou svou bytostí v lidové půdě, budiž jednim z př̀kladů i povzbuzeni, jaké nezdolné tvuirč́ síly a jaká nezlomná vi̊le k samostatnému a svobodnému tvưrčímu životu jsou skryty v našem lidu. A budiž ukazatelem, kterak cesta utrpeni

137 „Tento lidový život probudil v Janáckově nitru opět dřimajici síly, které mu tam vložili jeho otcové. Byly to lidové kořeny jeho rodu. Nebot’ málokterý z našich skladatelů vyrostl z tak přimých lidových kořenů jako Leoš Janáček. Proto byl jeho zájem o lidový život, o řě a písen lidu tak živelný a tak hluboce pronikajicí k podstatě věci, jakmile byl probuzen [...]. $Z$ těchto základi̊ roste pak Janáčkiov realismus." Ibid., s. 79-80.

138 HELFERT, V. Leoš Janáček. Obraz životního a uměleckého boje I. V poutech tradice. Brno: Ol. Pazdírek, 1939, s. 5-6. 
a poniženi vede ke konečnému vítězstvi tehdy, kráčeji-li po ní lidé pevni a statečni, kteři se nedaji ani $v$ nejtragičtějši hodině zviklati ve své viŕre ve svobodný tviorči život a v lepši zítřek. "139

Helfertovo přijetí Janáčka se v roce 1939 - snad i pod tíhou historické situace - dovršilo v knize Co daly naše země Evropě a lidstvu: zařazením Janáčka mezi pět nejvýznačnějších zjevů moderní české hudby: po bok Smetany, Dvořáka, Suka a Nováka. ${ }^{140}$

\section{Závěry a diskuse}

Objasnění podobností a souvislostí Helfertovy koncepce Janáčka s jinými koncepcemi a diskurzy budiž úkolem dalšího bádání. Již zde však můžeme konstatovat, že Helfertova koncepce i s ní spojená rétorika zanechaly výrazné stopy zejména na psaní jeho žáka Jana Racka, jak dokumentuje kromě menších recenzí a novinových článků např. Rackova studie Janáček - dramatik z roku $1933 .{ }^{141}$

Navzdory proklamovanému metodologickému důrazu na objektivní, eidocentrické studium dějin „hudebního myšlení“ a „hudební tvořivosti“142 a odporu vůči výrazové estetice, psychologismu a hermeneutice ${ }^{143}$ podržuje Helfertova koncepce Janáčka z let 1925-1939 v zásadě duchovědný přístup, kombinovaný s tainovským pozitivistickým (či naturalistickým) materialismem. ${ }^{144}$ Zatímco ve svých studiích o hudebním baroku, v České moderni hudbě i jinde Helfert do značné míry opouští duchovědná a romantická východiska, směřuje k strukturálně „fenomenologickému“, případně sociologizujícímu výkladu, ve svých janáčkovských textech (těžko říct, zda „v hlubinách“, či „na povrchu“) zůstal romantikem až do konce života: osobnost autora-génia pro něj znamenala - přinejmenším implicitně - klíčovou instanci, jež dává dílu věrohodnost a svým zpưsobem je posvěcuje. ${ }^{145} \mathrm{~V}$ tom se Helfertova koncepce Janáčka zásadně podobá Nejedlého koncepci Velkého českého skladatele. ${ }^{146}$

139 Ibid., s. 7.

140 HELFERT, V. Moderní česká hudba na světovém foru. In Co daly naše země Evropě a lidstvu. Praha: Sfinx, 1939, s. 190-192. Cit. dle Helfert, O české hudbě, op. cit., s. 105.

141 RACEK, Jan. Janáček - dramatik. Divadelni list Národního divadla v Brně, 1932-33, roč. 8, č. 14 (15. 2. 1933), s. 366-370.

142 K Helfertově metodologii srov. též POLEDŇÁK, Ivan. K metodologické problematice díla Vladimíra Helferta. Opus musicum, 1975, roč. 7, č. 10, s. 290-292. Poledňák konstatuje Helfertovo překonání „historiografického pozitivismu“ a „ideografismu“ v tom smyslu, že „Helfert ,koncipoval' svá fakta tak, aby byla v určité miřre i obecným a abstraktním poznatkem".

143 POLEDŇÁK, K některým otázkám, op. cit., s. 500.

144 Pečman píše v souvislosti s filosoficko-estetickými východisky Helfertova učitele Hostinského: „V druhé polovině 19. století působi na rozvoj estetického myšlení v Evropě hlavně Tainưv pozitivismus a německá idealistická filozofie“. PEČMAN, Rudolf. Útok na Antonína Dvořáka. Brno: Filozofická fakulta Masarykovy univerzity, 1992, s. 17.

145 Srov. HRABAL, op. cit., s. 15. K této obecné funkci instituce autora srov. zejm. FOUCAULT, Michel. Řád diskurzu. In Michel Foucault. Diskurs, autor, genealogie: 3 studie. Praha: Svoboda, 1994, s. 16.

146 Srov. ZAPLETAL, Mezi géniem a světcem, op. cit., s. 69-89. 
Na různých místech této studie jsme v konkrétních situacích připomínali podobnost Helfertových výroků o Janáčkovi s výroky Diltheyovými. Aniž bychom zde chtěli provádět analýzu filosofických a jiných zdrojů Helfertovy koncepce, zastavme se alespoň v několika bodech u zjevného konceptuálního vlivu diltheyovské duchovědy, ${ }^{147}$ jejž jsme konstatovali též v prrípadě Nejedlého. Zejména se zaměřme na Diltheyovu knihu Das Erlebnis und die Dichtung, po roce 1906 hojně čtenou v českých intelektuálních kruzích. ${ }^{148}$ Podle Diltheye se má hermeneutické bádání v prvé řadě soustředit na umělcův prožitek (Erlebnis), a ten reobjektivizovat znovuprožitím (Nacherleben). Patos, s jakým Helfert pojednává Janáčkovo utrpení a prožitkové kořeny jeho tvorby, prozrazují Helfertovu snahu o autentické pochopení Janáčkova díla skrze takovéto znovuprožití. Helfertův psychologizující výklad má blízko k diltheyovskému přístupu založenému na vcitování a vmýšlení se do jedinečné subjektivity umělce a snaze porozumět (Verstehen), jak se tyto subjektivní podmínky objektivizovaly v umělcově díle. V případě Helfertova psaní o Janáčkovi (a to nejen v textech úžeji hudebně-kritických, ale obecně, tedy i v hudebně-historických pracích) tento subjektivistní, duchovědný typ studia „hudebního myšlení převažuje nad typem formalistně orientovaným, snažícím se o objektivně prokazatelné vysvětlení (Erklerung) vývojových proměn hudebních struktur.

Kromě Diltheye jsme opakovaně konstatovali zřetelný vliv tainovského materialistického positivismu. ${ }^{149}$ Hippolyte Taine, literární historik a filosof, jehož vliv byl po roce 1865 mimořádně silný nejen ve Francii, formuloval svou metodologii literárně-historického výzkumu v Úvodu k Dějinám anglické literatury (1864), jejichž první díl u nás vyšel v českém překladu už v roce 1902 a jejichž recepce byla v intelektuálních kruzích čilá, o čemž svědčí mnohé dobové dokumenty. ${ }^{150}$ Taine je psychologista a materialistický determinista: tvrdí, že „vnějšri" člověk je cele toliko projevem člověka „vnitřního“; všechny „vnějškovosti“, jež tedy může historik literatury zkoumat, ,jsou jen př́stupové cesty, jež se sbihaji v jistém středu, a vy se po nich vydáváte jen, abyste se do toho středu dostal; tam spočivá pravý člověk, chci ř́ci skupina schopnosti a citů, jež způsobuji vše ostatni"; pravých historikovým objektem je tedy tento „podzemni svět", historikovým úkolem je rozebírat „psychologii“. Správné zkoumání se však nemá zastavovat u "fakt“, ale má hledat jejich „př́íciny“, jež vždy existují a vždy jsou poznatelné. Zkoumání těchto příčin vede k odhalení přísně deterministického řetězce

147 Vliv duchovědy (nejen Diltheye, ale též Maxe Dvořáka a F. X. Šaldy) na Helferta a ostatní Helfertova filosofická východiska poměrně podrobně diskutuje Hrabal, viz HRABAL, op. cit., s. 13-15 ff.

148 Vliv diltheyovské duchovědy na Helfertovo muzikologické myšlení naznačil Pečman. PEČMAN, Útok na Antonina Dvořáka, op. cit., s. 115.

149 Pečman konstatoval silný vliv tainovského „telurického“ pozitivismu na Nejedlého, zejména na jeho velkou smetanovskou monografii. Ibid., s. 48-49.

150 Srov. např. lidovýchovný přehled FIŠER, J. J. Stručné dějiny světové literatury. Nusle: F. Svoboda, 1925, s. 177. O Tainovi hojně psal F. X. Śalda. Samostatně jej pojedla roku 1902 Tille, viz TILLE, Václav. Filosofie literatury u Taina a předchůdců. Praha: Jan Laichter, 1902. Arne Novák napsal: „...biologická nauka Darwinova [...] stala se obecným majetkem vzdělanců i polovzdělanců, až nabyla pochybné podoby laického náboženství, zvláště když důmyslnými a upř́lišněnými výklady Tainovými o plemeni a prostředi byla nesena $i$ do filosofie dějin [...]. Chvílemi se zmocňovala ducha až optimistická víra, že vědecké poznáni pronikne všemi záhadami světa mechanického $i$ myšlenkového, a z toho temenil naukový osobivý titanismus." NOVÁK, Arne - NOVÁK, Jan V. Přehledné dějiny literatury české od nejstaršich dob až po naše dny. Olomouc: R. Prombergr, 1936, s. 641-642. Zvýraznil M.Z. Taina kritizoval nejpozději v roce 1901 též Masaryk, viz MASARYK, Tomáš Garrigue. Ideály humanitní. Praha: Melantrich, 1968, s. 49-50. 
faktorů. Sledujíce tento řetěz až $\mathrm{k}$ jeho počátku dospějeme nutně $\mathrm{k}$ „povaze“ a „duchovni skladbe "rasy“, jež jsou zase formovány prostředím a podnebím svého původu: tak nap̌r. protestantské umění je podmíněno protestantismem obecně, jenž je zase podmíněn charakterem Seveřanů, a tento je v posledku určen severským podnebím. Velmi podobný řetězec determinant jsme konstatovali výše v Helfertově koncepci Janáčka. Kromě „rasy“ a „prostředi" je podle Taina třetím hlavním faktorem „dějinná chvile“. ${ }^{151}$ Tato optimální dějinná chvíle podle Helferta nastala pro Janáčka po roce 1918: tehdy jeho hudba najednou plně odpovídala „nové době", a proto se teprve tehdy mohl dočkat úspěchu.

Můžeme tuto studii uzavř́ít konstatováním zjištění, že vše, co Helfert napsal o Janáčkovi po roce 1924, už rozvíjelo hotovou koncepci Janáčka, jejíž základní rysy jsme zmínili výše, a že tato koncepce v sobě spájela metodologicky inovativní důraz na strukturální, „fenomenologickou“ analýzu hudebního objektu a dějiny „hudebního myšlení" na jedné straně s romantickým, duchovědným a pozitivisticko-materialistickým základem na straně druhé.

Úplným závěrem chceme polemizovat s jedním tvrzením Jindřišky Bártové. Bártová píse o Helfertovi v době jeho pražského pobytu: „...snažil se následovat jeho [Nejedlého] př̌kladu vytvárénim ideových konstrukci podobně krkolomných, jako byly konstrukce Nejedlého [...]. Je pozoruhodné a př́značné, že veškeré Helfertovy konstrukce a výpady po jeho odchodu do Brna ustávaji“ ${ }^{152}$ Jedním z výsledků této studie budiž právě zjištění, že Helfert se po přechodu do Brna „konstrukcí“ nijak nezř̌kl (at̉ už by to bývalo bylo možné, či ne), pouze své dřívější konceptuální konstrukty částečně transformoval a částečně nahradil jinými. A patos, s nímž před rokem 1919 bojoval proti Janáčkovi, se přetavil v neméně silný patos, s nímž od poloviny dvacátých let čím dál více brojil za pravdu nově poznanou: tedy za Janáčka.

151 TAINE, Hippolyte. Úvod. In Hippolyte Taine. Studie o dějinách a umění. Praha: Odeon, 1978, s. 91-96. K podobné formulaci téhož srov. TAINE, Hippolyte. Filosofie uměni. Praha: Josef Pelcl, 1913, s. 57 ff. Velmi podobně však uvažuje též Adler, viz ADLER, Der Stil in der Musik, op. cit., s. 13.

152 BÁRTOVÁ, Podivnosti kritických soudů, op. cit., zejm. s. 22. 


\section{Bibliography}

\section{Sources}

ADLER, Guido. Der Stil in der Musik. I. Buch: Prinzipen und Arten des Musikalischen Stils. Leipzig: Breitkopf \& Härtel, 1911.

ČERNUŠÁK, Gracian - HELFERT, Vladimír Helfert (eds.). Pazdirki̊v hudebni slovnik naučný. II., Část osobni. Svazek pruý, A-K. Brno: Ol. Pazdírek, 1937.

DILTHEY, Wilhelm. Das Erlebnis und die Dichtung: Lessing, Goethe, Novalis, Hölderlin. Vyd. 8. Leipzig und Berlin: Verlag B. G. Teubner, 1922.

FIŠER, J. J. Stručné dějiny světové literatury. Nusle: F. Svoboda, 1925.

HELFERT, V. Převrácený kalendář? Smetana, 1911/1912, roč. 2, č. 8/9, s. 132.

HELFERT, V. „Jungböhmische Musik“, Smetana, 1912/1913, roč. 3, č. 4/5, s. 48-51.

HELFERT, V. Jaroslav Jeremiáš: Ad vocem Janáčkova „Pastorkyňa“ a - Smetana. Smetana, 1916/1917, roč. 7, č. 3, s. 46-47.

HELFERT, V. České symfonické koncerty. Národ, 1917, roč. 1, č. 34 (22. 11. 1917), s. 609-610.

HELFERT, V. Naše hudba a český stát. Praha: B. Kočí, 1918.

HELFERT, V. Brněnská konservatoř. Socialistická budoucnost, 1920, roč. 18, č. 72 (28. 3. 1920), s. 1. HELFERT, V. Koncerty. Moravské noviny, roč. 43, č. 95 (26. 4. 1922), s. 1.

HELFERT, V. Tvưrči rozvoj Bedřicha Smetany. I. Preludium k životnímu dílu. Praha: Jos. R. Vilímek, 1924.

HELFERT, V. Janáčkovy oslavy v Brně. Hudebni rozhledy, 1924/1925, roč. 1, č. 3/4, s. 66-68.

HELFERT, V. Max Brod: Leoš Janáček, život a dílo. Hudebni rozhledy, 1924/1925, roč. 1, č. 3/4, s. 71-72.

HELFERT, V. Moravská a pražská „svojskost“. Hudebni rozhledy, 1924/1925, roč. 1, č. 5, s. 90.

[HELFERT, V.?]. Kriteria. Hudebni rozhledy, 1924/1925, roč. 1, č. 5, s. 90.

HELFERT, V. Čeho je potřeba. Hudebni rozhledy, 1924-1925, roč. 1, č. 1/2, s. 1-4.

HELFERT, V. Opera v Brně. Ruch, 1925, roč. 1, č. 42 (21. 2. 1925), s. 2.

HELFERT, V. Opera Národního divadla. Ruch, 1925, roč. 1, č. 258 (13. 11. 1925), s. 1-2.

HELFERT, V. K otázce našeho hudebního folkloru. Morava, 1925, roč. 1, č. 8, s. 230-236.

HELFERT, V. L. Janáček: Suita pro smyčcový orchestr. Hudebni rozhledy, 1925/1926, roč. 2, č. 8, s. 131.

HELFERT, V. P. Kř́žkovský a B. Smetana. Morava, 1926, roč. 2, č. 6, s. 161-174.

HELFERT, V. Janáčkova nová opera. Ruch, 1926, roč. 2, č. 291 (21. 12. 1926), s. 1-2.

HELFERT, V. Národní divadlo v Brně. Hudebni rozhledy, 1926/1927, roč. 3, č. 4/5, s. 79-80.

HELFERT, V. Brněnské koncerty. Hudebni rozhledy, 1926/1927, roč. 3, č. 9/10, s. 152.

HELFERT, V. Symfonietta. Hudebni rozhledy, 1926/27, roč. 3, č. 7, s. 111-112.

HELFERT, V. Koncerty v Brně. Ruch, 1927, roč. 3, č. 80 (5. 4. 1927), s. 3.

HELFERT, V. Hudba v Brně. Ruch, 1927, roč. 3, č. 280 (8. 12. 1927), s. 1-2.

HELFERT, V. Leoš Janáček. Ruch, 1928, roč. 4, č. 189 (19. 8. 1928), s. 2-3.

HELFERT, V. Janáčkův Mrtvý dům. Ruch, 1930, roč. 6, č. 98 (15. 4. 1930), s. 1-2.

HELFERT, V. Brod Max, Leoš Janáček, Život a dílo. Veselý Adolf, Leoš Janáček, Pohled do života i díla. Vašek Adolf E., Po stopách dra Leoše Janáčka. Kapitoly a dokumenty k jeho životu a dílu. Muller Daniel, Leoš Janáček. Časopis Matice moravské, 1931, roč. 55, s. 538-548.

HELFERT, V. Nové knihy. Index, 1931, roč. 3, č. 1, s. 12; č. 2, s. 24.

HELFERT, V. Slovanská katharse. Divadelni list Zemského divadla v Brně, 1932-1933, roč. 8, č. 9 (7. 12. 1932), s. 231-232. 
HELFERT, V. Pohled na Bedřicha Smetanu. Brno: Index, 1934.

HELFERT, V. Bolestný zdroj Janáčkovy Pastorkyně. Magazin Družstevni práce, 1934/1935, roč. 2, č. 5, s. 146-149.

HELFERT, V. Z předmluvy ke třetímu vydání Její Pastorkyně. Tempo, 1934/1935, roč. 14, č. 4, obálka (její 4. str.).

HELFERT, Vladimír - STEINHARD, Erich. Geschichte der Musik in der Tsechoslovakischen Republik. Prag: Orbis, 1936.

HELFERT, V. Závaznost dokumentu. Index, 1937, roč. 9, č. 6, s. 65-66.

HELFERT, V. Janáčkova elegie nad ztrátou dcery Olgy. Hudebni noviny, 1937/1938, roč. 5, s. 18.

HELFERT, Vladimír - STEINHARD, Erich. Die Musik in der Tschechoslovakischen Republik. Prag: Orbis, 1938.

HELFERT, V. Leoš Janáček. Obraz životniho a uměleckého boje I. V poutech tradice. Brno: Ol. Pazdírek, 1939.

HELFERT, Vladimír. O Janáckovi. Soubor stati a článkủ. Praha: Hudební matice Umělecké besedy, 1949.

HELFERT, V. O Smetanovi: soubor stati a clánků. Praha: Hudební matice, 1950.

HELFERT, Vladimír. O české hudbě. Praha: SNKLHU, 1957.

HELFERT, Vladimír. Vybrané studie I. O hudebni tvořivosti. Praha: Editio Supraphon, 1970.

MASARYK, Tomáš Garrigue. Ideály humanitni. Praha: Melantrich, 1968.

NOVÁK, Arne - NOVÁK, Jan V. Přehledné dějiny literatury české od nejstař̌ích dob až po naše dny.

Olomouc: R. Prombergr, 1936.

JANÁČEK, Leoš. Výlety páně Broučkovy. Lidové noviny, 1917, roč. 25, č. 351 (23. 12. 1917), s. 1.

JANÁČEK, Leoš. Jeji pastorkyña. Klavirni výtah se zpěvy. Praha: Hudební matice Umělecké besedy, 1934.

JANÁČEK, Leoš. Amarus. Praha: Hudební matice Umělecké besedy, 1938.

KOŽÍŠEK, Alois V. (ed.). Zemské hlavni město Brno. Praha: E. Šolc, 1928.

KOŽÍŠEK, Alois V. (ed.). Die Landeshauptstadt Brünn. Prag-Karlín: E. Šolc, 1928.

RACEK, Jan. Janáček - dramatik. Divadelni list Národního divadla v Brně, 1932-33, roč. 8, č. 14 (15. 2. 1933), s. 366-370.

ROLLAND, Romain. Život Beethovenưv. Praha: B. Kočí, 1919.

ŠALDA, František Xaver. Duše a dilo: podobizny a medailony. Praha: Melantrich, 1937.

ŠALDA, František Xaver. Boje o zitřek. Duše a dilo. Praha: Melantrich, 1973.

TAINE, Hippolyte. Filosofie uměni. Praha: Josef Pelcl, 1913.

TAINE, Hippolyte. Studie o dějinách a umění. Praha: Odeon, 1978.

TILLE, Václav. Filosofie literatury u Taina a predchi̊dců. Praha: Jan Laichter, 1902.

\section{Literature}

BÁRTOVÁ, Jindra. Postoje Vladimíra Helferta k českým skladatelům po Bedřichu Smetanovi. Opus musicum, 1986, roč. 18, č. 6, s. 163-165.

BÁRTOVÁ, Jindra. Podivnosti kritických soudů v českém hudebním časopisectví na počátku století. Opus musicum, 1999, roč. 31, č. 4, s. 9-23.

BURJANEK, Josef. Poznámky k estetice Vladimíra Helferta. Hudebni rozhledy, 1975, roč. 28, č. 6, s. 270-273. 
BURNHAM, Scott. Criticism, Faith, and the Idee: A. B. Marx's Early Reception of Beethoven. 19thCentury Music, 1990, roč. 13, č. 3, s. 183-192.

COOK, Nicholas - EVERIST, Mark (eds.). Rethinking Music. Oxford: Oxford University Press, 2010.

FOUCAULT, Michel. Diskurs, autor, genealogie: 3 studie. Praha: Svoboda, 1994.

Helfertova Česká moderni hudba. Praha: HAMU, 1996.

HONS, Miloš. Boj o českou moderni hudbu (1900-1939). Praha: Togga, 2013.

KANT, Immanuel. Kritika soudnosti. Praha: Odeon, 1975.

KERMAN, Joseph. How We Got into Analysis, and How to Get Out. Critical Inquiry, 1980, roč. 7, č. 2, s. 311-331.

MAJER, Jiří. Vklad hudebnímu časopisectví. Opus musicum, 1975, roč. 7, č. 10, s. 299-301.

MÜLLER, Richard - ŠIDÁK, Pavel (eds.). Slovnik novějši literárni teorie: glosár̆ pojmů. Praha: Academia, 2012.

PEČMAN, Rudolf. Útok na Antonína Dvořáka. Brno: Filozofická fakulta Masarykovy univerzity, 1992.

PEČMAN, Rudolf. Vladimir Helfert. Brno: Nadace Universitas Masarykiana, 2003.

POLEDŇÁK, Ivan. K některým otázkám Helfertovy estetiky. Hudebni rozhledy, 1957, roč. 10, č. 12, s. 500-502.

POLEDŇÁK, Ivan. Soupis prací Vladimíra Helferta. Musikologie, 1958, č. 5, s. 253-313.

POLEDŇÁK, Ivan. K metodologické problematice díla Vladimíra Helferta. Opus musicum, 1975, roč. 7, č. 10, s. 290-292.

POSPÍŠIL, Milan. Bedřich Smetana v pojetí Elišky Krásnohorské. Hudebni věda, 1995, roč. 32, č. 1, s. $42-54$.

SYCHRA, Antonín. Vladimír Helfert a smysl české hudby. Hudebni rozhledy, 1961, roč. 14, č. 5, s. $184-187$.

Vladimír Helfert v českém a europském kontextu. Brno: Svaz českých skladatelů a koncertních umělců, 1987.

VYSLOUŽIL, Jiří. Index - tribuna Helfertových kritických syntéz. Index, 1968, roč. 1, č. 7, s. 24-29; č. 8, s. 22-25.

VYSLOUŽIL, Jiří. Vladimír Helfert as a Critic of Music. SPFFBU, 1969, H4 (roč. 4), č. 18, s. 49-66. VYSLOUŽIL, Jiří. Léta brněnského působení Vladimíra Helferta. Opus musicum, 1975, roč. 7, č. 10, s. 293-298.

ZAGORSKI, Marcus. Hearing Beethoven, Truth, and "New Music". International Review of the Aesthetics and Sociology of Music, 2013, roč. 44, č. 1, s. 49-56.

ZAPLETAL, Miloš. Mezi géniem a světcem: Dekonstrukce Nejedlého koncepce velkého českého skladatele. Musicologica Brunensia, 2015, roč. 50, č. 2, s. 69-89.

ZVARA, Vladimír. Leoš Janáček and the „Slavic catharsis“. International Review of the Aesthetics and Sociology of Music, 2012, roč. 43, č. 1, s. 23-34.

ŻERAŃSKA-KOMINEK, Sławomira (ed.). Nationality vs. Universality: Musical Historiographies in Central and Eastern Europe. Cambridge: Cambridge Scholars Publishing, 2016. 
